\title{
WASTE_MGMT: A Computer Model for Calculation of Waste Loads, Profiles, and Emissions
}

by T.J. Kotek, H.I. Avci, and B.L. Koebnick

Environmental Assessment Division,

Argonne National Laboratory, 9700 South Cass Avenue, Argonne, Illinois 60439

April 1995

Work sponsored by United States Department of Energy, Assistant Secretary for Environmental Management 


\section{DISCLAIMER}

Portions of this document may be illegible in electronic image products. Images are produced from the best available original document. 


\section{CONTENTS}

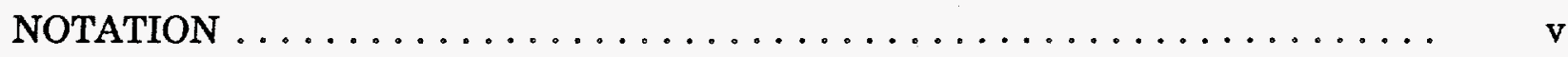

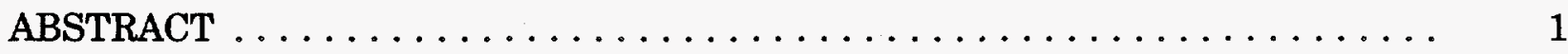

1 INTRODUCTION $\ldots \ldots \ldots \ldots \ldots \ldots \ldots \ldots \ldots \ldots \ldots \ldots \ldots \ldots \ldots \ldots \ldots$

2 DESCRIPTION OF MODEL INPUT . . . . . . . . . . . . . . . 3

2.1 Waste Inventory and Characterization $\ldots \ldots \ldots \ldots \ldots \ldots \ldots . .3$

2.2 TSD Facility Characterization $\ldots \ldots \ldots \ldots \ldots \ldots \ldots \ldots \ldots \ldots \ldots \ldots \ldots \ldots$

2.3 Alternative Definition $\ldots \ldots \ldots \ldots \ldots \ldots \ldots \ldots \ldots \ldots \ldots \ldots \ldots \ldots \ldots$

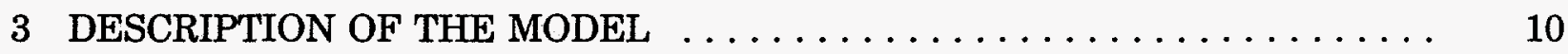

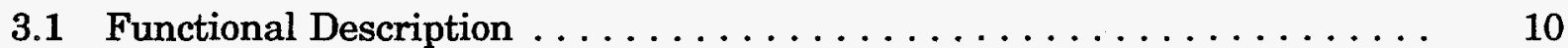

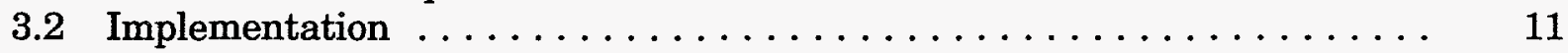

4 DESCRIPTION OF MODEL OUTPUT $\ldots \ldots \ldots \ldots \ldots \ldots \ldots \ldots \ldots \ldots \ldots$

5 APPLICATION OF THE WASTE_MGMT MODEL $\ldots \ldots \ldots \ldots \ldots \ldots \ldots$

5.1 Data Distributions . . . . . . . . . 16

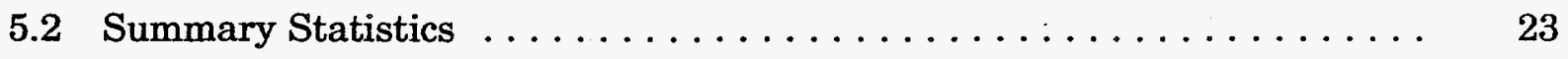

6 FURTHER DEVELOPMENT OF THE WASTE_MGMT MODEL . . . . . . 26

7 REFERENCES $\ldots \ldots \ldots \ldots \ldots \ldots \ldots \ldots \ldots \ldots \ldots \ldots \ldots \ldots \ldots \ldots \ldots \ldots \ldots \ldots \ldots$

APPENDIX: WASTE_MGMT FILES $\ldots \ldots \ldots \ldots \ldots \ldots \ldots \ldots \ldots \ldots \ldots \ldots$

\section{FIGURE}

1 Schematic of a Treatment Train for a LLW Waste Stream ..........

\section{TABLES}

1 THR: Waste Inventory Annual Throughput $\ldots \ldots \ldots \ldots \ldots \ldots \ldots .4$

2 NUC: Waste Inventory Radiological Profile $\ldots \ldots \ldots \ldots \ldots \ldots \ldots \ldots$

3 CHM: Waste Inventory Hazardous Contaminant Profile $\ldots \ldots \ldots \ldots \ldots$ 


\section{TABLES (Cont.)}

4 TCH_PRAM: Treatment, Storage, and Disposal Facility

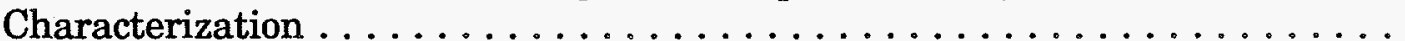

5 REL_FRAC: TSD Radiological Partitioning Coefficients . . . . . . . . . 6

6 REL_CHEM: TSD Hazardous Contaminant Partitioning Coefficients

7 ALTERNTS: Alternative Definition for WASTE_MGMT $\ldots \ldots \ldots \ldots \ldots .8$

8 Alternative Definition of a Treatment Train for a LLW

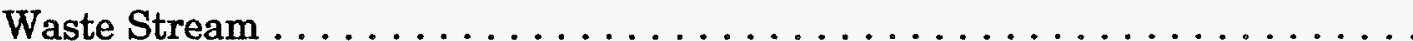

9 THRT: WASTE_MGMT Substream Throughput $\ldots \ldots \ldots \ldots \ldots \ldots \ldots \ldots$

10 THRN and AIRN: WASTE_MGMT Substream Radiological Profile and Releases . . . . . . . . . . . . . . . . . . .

11 THRC and AIRC: WASTE_MGMT Substream Hazardous Contaminant Profile and Releases $\ldots \ldots \ldots \ldots \ldots \ldots \ldots \ldots$

12 Data Structures: Throughput and Profile by Site, Technology,

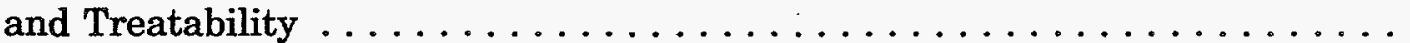

13 Radiological and Hazardous Contaminant Air Releases by Site . . . . . . . 19

14 Throughput and Transportation Summary by Site, Technology,

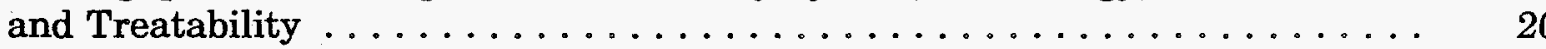

15 Contaminant Profiles of Transported Wastes $\ldots \ldots \ldots \ldots \ldots \ldots \ldots \ldots 21$

16 Throughput and Contaminant Profiles of Intermediate Substreams . . . . . . 22

17 Throughput and Contaminant Profiles by Site and Technology ......... 24

18 Representative WASTE_MGMT Execution Times and File Sizes $\ldots \ldots \ldots \ldots 25$

A.1 Alternative Numbering Convention $\ldots \ldots \ldots \ldots \ldots \ldots \ldots \ldots \ldots \ldots$ 


\section{NOTATION}

The following is a list of acronyms, initialisms, and abbreviations (including units of measure) used in this document.

\section{ACRONYMS, INITIALISMS, AND ABBREVIATIONS}

\section{General}

$\begin{array}{ll}\text { ANL-E } & \text { Argonne National Laboratory-East } \\ \text { BAPL } & \text { Bettis Atomic Power Laboratory } \\ \text { CH } & \text { contact-handled (waste) } \\ \text { DOE } & \text { U.S. Department of Energy } \\ \text { EM } & \text { environmental management } \\ \text { ER } & \text { environmental restoration } \\ \text { HANF } & \text { Hanford Site } \\ \text { HLW } & \text { high-level waste } \\ \text { HW } & \text { hazardous waste } \\ \text { INEL } & \text { Idaho National Engineering Laboratory } \\ \text { LBL } & \text { Lawrence Berkeley National Laboratory } \\ \text { LLMW } & \text { low-level mixed waste } \\ \text { LLNL } & \text { Lawrence Livermore National Laboratory } \\ \text { LLW } & \text { low-level waste } \\ \text { MWTP } & \text { Mixed Waste Treatment Project } \\ \text { NTS } & \text { Nevada Test Site } \\ \text { ORNL } & \text { Oak Ridge National Laboratory } \\ \text { PEIS } & \text { Programmatic Environmental Impact Statement } \\ \text { RH } & \text { remote-handled (waste) } \\ \text { TRUW } & \text { transuranic waste } \\ \text { TSD } & \text { treatment, storage, and disposal } \\ \text { WM } & \text { waste management }\end{array}$

\section{Contaminants}

$\begin{array}{ll}\mathrm{Ag} & \text { silver } \\ \mathrm{As} & \text { arsenic } \\ \mathrm{Ba} & \text { barium } \\ \mathrm{C} & \text { carbon } \\ \mathrm{Cd} & \text { cadmium } \\ \mathrm{Cl}-2-\mathrm{x} & \text { di-chloro-hydrocarbons } \\ \text { Cl-3-x } & \text { tri-chloro-hydrocarbons } \\ \text { Cl-4-x } & \text { tetra-chloro-hydrocarbons } \\ \mathrm{Cl}-\mathrm{F}-\mathrm{x} & \text { chloro-fluoro-hydrocarbons } \\ \mathrm{Cm} & \text { curium } \\ \mathrm{Co} & \text { cobalt } \\ \mathrm{Cr} & \text { chromium }\end{array}$




\section{NOTATION (Cont.)}

\section{Contaminants (Cont.)}

$\begin{array}{ll}\mathrm{Cs} & \text { cesium } \\ \mathrm{Eu} & \text { europium } \\ \mathrm{Fe} & \text { iron } \\ \mathrm{H}-3 & \text { tritium } \\ \mathrm{HC}-\text { insolub } & \text { benzene, toluene, xylene } \\ \mathrm{HC}-\text { soluble } & \text { acetone, butanone, methanol } \\ \mathrm{Hg} & \text { mercury } \\ \mathrm{Mn} & \text { manganese } \\ \mathrm{Nb} & \text { niobium } \\ \mathrm{Ni} & \text { nickel } \\ \mathrm{Pa} & \text { protactinium } \\ \mathrm{PCB} & \text { polychlorinated biphenyl } \\ \mathrm{Pb} & \text { lead } \\ \mathrm{Pm} & \text { promethium } \\ \mathrm{Pu} & \text { plutonium } \\ \mathrm{Sb} & \text { antimony } \\ \mathrm{Se} & \text { selenium } \\ \mathrm{Sm} & \text { samarium } \\ \mathrm{Sr} & \text { strontium } \\ \mathrm{Tc} & \text { technetium } \\ \mathrm{Te} & \text { tellurium } \\ \mathrm{Th} & \text { thorium } \\ \mathrm{U} & \text { uranium } \\ \mathrm{Y} & \text { yttrium } \\ \mathrm{Zr} & \text { zirconium } \\ & \end{array}$

\section{UNITS OF MEASURE}

$\begin{array}{ll}\mathrm{Ci} & \text { curie(s) } \\ \mathbf{k g} & \text { kilogram(s) } \\ \mathrm{m}^{3} & \text { cubic meter(s) } \\ \mathrm{MHz} & \text { megahertz } \\ \mu \mathrm{g} & \text { microgram(s) } \\ \mathrm{nCi} & \text { nanocurie(s) } \\ \mathrm{ppm} & \text { part(s) per million } \\ \mathrm{yr} & \text { year(s) }\end{array}$




\title{
WASTE_MGMT: A COMPUTER MODEL FOR CALCULATION OF WASTE LOADS, PROFILES, AND EMISSIONS
}

by

\author{
T.J. Kotek, H.I. Avci, and B.L. Koebnick
}

\begin{abstract}
WASTE_MGMT is a computational model that provides waste loads, profiles, and emissions for the U.S. Department of Energy's Waste Management Programmatic Environmental Impact Statement (WM PEIS). The model was developed to account for the considerable variety of waste types and processing alternatives evaluated by the WM PEIS. The model is tabledriven, with three types of fundamental waste management data defining the input: (1) waste inventories and characteristics; (2) treatment, storage and disposal facility characteristics; and (3) alternative definition. The primary output of the model consists of tables of waste loads and contaminant profiles at facilities, as well as contaminant air releases for each treatment and storage facility at each site for each waste stream. The model is implemented in Microsoft ${ }^{\circledR}$ FoxPro ${ }^{\circledR}$ for MS-DOS ${ }^{\circledR}$ version 2.5 and requires a microcomputer with at least a 386 processor and a minimum 6 MBytes of memory and 10 MBytes of disk space for temporary storage.
\end{abstract}

\section{INTRODUCTION}

This report describes the Argonne National Laboratory-East (ANL-E) WASTE_MGMT relational database management system that has been designed and implemented to provide an upper-level asseissment of alternative, integrated approaches to the management of existing and future wastes at U.S. Department of Energy (DOE) facilities. The system was initially designed to support analyses for the DOE Waste Management Programmatic Environmental Impact Statement (WM PEIS) (DOE 1995).

The WM PEIS is being implemented to evaluate the strategies for alternative siting configurations for the treatment, storage, and disposal (TSD) of DOE wastes belonging to five general categories: high-level waste (HLW), low-level waste (LLW), transuranic waste (TRUW), low-level mixed waste (LLMW), and chemical hazardous waste (HW). The siting configurations considered generally fall under three classifications: decentralized, regionalized, and centralized. Under the decentralized alternative, the wastes are generally treated and stored at the sites where they are generated and disposed of at 16 sites throughout the country. Treatment and storage occur primarily at some regional and central locations under the regionalized and centralized alternatives, respectively. A no-action 
alternative (that includes only existing or approved waste management facilities) is also considered.

Under each decentralized, regionalized, and centralized alternative, there may be several cases with different siting arrangements for each waste type. In addition, more than one treatment option may be considered for each waste type. Consequently, the number of cases (i.e., site-technology combinations) to be analyzed varies from one waste type to another.

The WASTE_MGMT model described in this report was developed by ANL-E in response to the requirement of the WM PEIS to accurately and efficiently evaluate critical parameters associated with the complex array of waste inventories with multiple technology and siting options for TSD. An additional objective of the WASTE_MGMT model development was to provide the results of these parameter evaluations in a format that could be easily interpreted and transmitted for further use by ANL-E and other participants in the overall WM PEIS program for the evaluation of associated impacts. The uses of the WASTE_MGMT model results in the WM PEIS program are also briefly outlined in this report.

The WASTE_MGMT model was used for the evaluation of alternative strategies for the management of three of the waste types considered in the WM PEIS: LLW, LLMW, and TRUW. Because of the unique features of HLW and HW, the alternatives for these two waste types were evaluated with approaches that were specifically designed for them. The application of the WASTE_MGMT model for the evaluation of LLW, LLMW, and TRUW alternatives are discussed further in Sections 2 through 5. 


\section{DESCRIPTION OF THE MODEL INPUT}

WASTE_MGMT uses three types of input in its computations: (1) waste inventory and characterization; (2) TSD facility characterization; and (3) alternative definition. Because the computational model is used for several types of waste, the input data are specific for a given waste type. However, the formats of the data, with a few minor exceptions, are the same for all waste types.

\subsection{WASTE INVENTORY AND CHARACTERIZATION}

Waste inventories are identified by generating site, handling characteristic (e.g., contact-handled alpha), treatability category, stored volume, annual volume generation rate, and contaminant profile. The stored volume and annual generation rate are converted to an effective annual volume throughput rate, in $\mathrm{m}^{3} / \mathrm{yr}$, for the model computations. The throughput rate depends on alternative specific assumptions made for the time periods of waste generation and waste processing. For example, the assumptions for waste management (WM) LLMW were a 20-year generation period during which newly generated waste would be stored for the first 10 years (time required to construct new facilities), followed by a 10-year period during which all of the stored waste and newly generated waste would be processed. The assumption for environmental restoration (ER) LLMW was that all waste would be processed during a 30-year period. Waste volumes used within the model assume standardized densities for waste that is unpacked and void free. Because the waste volumes described by the input may be gross volumes that include voids due to partially packed waste containers, the gross volumes are normalized to standard stream densities defined by the model.

The waste volumes are specified separately by each waste-handling characteristic and by waste-treatability category defined for a given waste type. For example, 10 waste treatability categories have been defined for LLW, and all LLW is considered to be either contact-handled $(\mathrm{CH})$ non-alpha waste or $\mathrm{CH}$ alpha waste. For comparison, 23 waste treatability categories have been defined for LLMW, which can have handling characteristics of $\mathrm{CH}$ non-alpha, $\mathrm{CH}$ alpha, remote-handled $(\mathrm{RH})$ non-alpha, $\mathrm{RH}$ alpha, $\mathrm{CH}$ non-alpha polychlorinated biphenyl (PCB) and $\mathrm{CH}$ alpha PCB waste. Contaminant profiles include both radiological distributions and hazardous material distributions, expressed as $\mathrm{Ci} / \mathrm{yr}$ by nuclide and $\mathrm{kg} / \mathrm{yr}$ by hazardous contaminant, respectively. Examples of these table entries for a single LLMW waste stream are shown in Tables 1,2 , and 3 . The entries are drawn from three generic database files: file THR contains volume and mass throughput values; file NUC contains the radiological profile; and file CHM contains the hazardous contaminant profile. (See the Appendix for descriptions of the data files used by WASTE_MGMT.) The waste inventory characterizations are waste-type dependent, and the actual files containing the data will differ in some of the fields due in part to the differing sources for data collection. 


\begin{tabular}{|c|c|c|c|c|c|c|c|c|c|c|c|}
\hline $\begin{array}{c}\text { Generating } \\
\text { site }\end{array}$ & $\begin{array}{c}\text { Treata } \\
\text { Cate } \\
\text { MWTP }\end{array}$ & $\begin{array}{l}\text { lity } \\
\text { ry } \\
\text { ANL }\end{array}$ & Handling & $\begin{array}{l}\text { Density } \\
(\mathrm{kg} / \mathrm{m} 3)\end{array}$ & $\underset{\mathrm{yr}}{\mathrm{Gen}}$ & $\begin{array}{c}\mathrm{Proc}_{-} \\
\mathrm{Yr}\end{array}$ & $\begin{array}{l}\text { Current } \\
\text { Inventory } \\
\text { (m3) }\end{array}$ & $\begin{array}{l}\text { Annual } \\
\text { Generation } \\
\left(\mathrm{m} 3 / \mathrm{yr}^{\mathrm{r}}\right)\end{array}$ & $\begin{array}{c}\text { Gross } \\
\text { Throughput } \\
\text { (m3/yr) }\end{array}$ & $\begin{array}{c}\text { Net } \\
\text { Throughput } \\
\text { (m3/yr) }\end{array}$ & $\begin{array}{c}\text { Net } \\
\text { Mass } \\
(\mathrm{kg} / \mathrm{yr})\end{array}$ \\
\hline INEL & 1100 & 01 & - & 1033 & 20 & 10 & $1.130 \mathrm{E}+02$ & $8.987 E-01$ & $1.309 \mathrm{E}+01$ & $1.218 \mathrm{E}+01$ & 1. $258 \mathrm{E}+04$ \\
\hline
\end{tabular}

This line is entered for each site and each waste treatability category (1-10 for LLW, 1-8 for TRUW and 1-23 for LLMW).

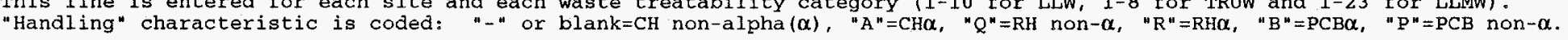

\section{TABLE 2 NUC: Waste Inventory Radiological Profile}

\begin{tabular}{|c|c|c|c|c|}
\hline \multirow{2}{*}{$\begin{array}{c}\text { Waste Type: } \\
\begin{array}{c}\text { Generating } \\
\text { Site }\end{array}\end{array}$} & \multicolumn{2}{|l|}{ LLMW } & \multicolumn{2}{|c|}{ Radiological Profile } \\
\hline & $\begin{array}{c}\text { Treatabil } \\
\text { Code }\end{array}$ & $\begin{array}{l}t_{Y} \\
\text { Handling }\end{array}$ & Nuclide & $\begin{array}{l}\text { Activity } \\
\text { (Ci/yr) }\end{array}$ \\
\hline INEL & 01 & - & $\mathrm{H}-3$ & $3.75106 E+01$ \\
\hline INEL & 01 & - & $M n-54$ & $5.46669 \mathrm{E}-02$ \\
\hline INEL & 01 & - & $\mathrm{Fe}-55$ & $1.72200 \mathrm{E}+01$ \\
\hline INEL & 01 & - & $\mathrm{Co}-60$ & $1.31715 \mathrm{E}+02$ \\
\hline INEL & 01 & -. & $\mathrm{Ni}-59$ & $1.72200 \mathrm{E}+00$ \\
\hline INEL & 01 & - & $\mathrm{Ni}-63$ & $2.31523 E+02$ \\
\hline INEL & 01 & - & $\mathrm{Sr}-90$ & $8.10893 \mathrm{E}+00$ \\
\hline INEL & 01 & - & $\mathrm{Y}-90$ & $8.10893 \mathrm{E}+00$ \\
\hline INEL & 01 & - & $\mathrm{Nb}-94$ & $8.20004 \mathrm{E}-02$ \\
\hline INEL & 01 & - & $S b-125$ & $3.64446 \mathrm{E}-02$ \\
\hline INEL & 01 & - & $\mathrm{Te}-125 \mathrm{~m}$ & $9.11116 \mathrm{E}-03$ \\
\hline INEL, & 01 & - & $\mathrm{Cs}-134$ & $7.74448 \mathrm{E}-02$ \\
\hline INEL & 01 & - & Cs -137 & $8.61004 \mathrm{E}+00$ \\
\hline INEL & 01 & - & $\mathrm{Ba}-137 \mathrm{~m}$ & $8.15449 \mathrm{E}+00$ \\
\hline INEL & 01 & - & $\mathrm{Pm}-147$ & $9.38449 \mathrm{E}-01$ \\
\hline INEL & 01 & - & $\mathrm{Sm}-151$ & $7.28893 \mathrm{E}-02$ \\
\hline INEL & 01 & - & Eu-154 & $1.04778 \mathrm{E}-01$ \\
\hline INEL & 01 & - & Eu-155 & $5.01113 \mathrm{E}-02$ \\
\hline INEL & 01 & - & $\mathrm{Th}-234$ & $3.23446 \mathrm{E}-01$ \\
\hline INEL & 01 & - & $\mathrm{Pa}-234 \mathrm{~m}$ & $3.23446 \mathrm{E}-01$ \\
\hline INEL & 01 & - & $U-238$ & $3.23446 \mathrm{E}-01$ \\
\hline INEL & 01 & - & $\mathrm{Pu}-238$ & $2.68779 \mathrm{E}-01$ \\
\hline INEL & 01 & - & $\mathrm{Pu}-241$ & $2.18667 \mathrm{E}-01$ \\
\hline
\end{tabular}

TPALE 3 CFM: Waste Inventory Hazardous Contaminant Profile

\begin{tabular}{|c|c|c|c|c|c|}
\hline \multirow{2}{*}{$\begin{array}{l}\text { Waste Type: } \\
\text { Generating } \\
\text { Site }\end{array}$} & \multicolumn{3}{|l|}{ LLMW } & \multicolumn{2}{|c|}{ Hazardous Contaminant Profile } \\
\hline & $\begin{array}{l}\text { Treat } \\
\text { Code }\end{array}$ & $\begin{array}{l}\text { ility } \\
\text { andling }\end{array}$ & Chem_id & Contaminant & $\begin{array}{l}\text { Amount } \\
(\mathrm{kg} / \mathrm{yr})\end{array}$ \\
\hline INEL & 01 & - & $57-12-5$ & cyanide & $6.29131 \mathrm{E}-01$ \\
\hline INEL & 01 & - & $75-09-2$ & methylene chloride & $1.25826 \mathrm{E}-01$ \\
\hline INEL & 01 & - & $\mathrm{Ag}$ & silver & $1.25826 \mathrm{E}-01$ \\
\hline INEL & 01 & - & As & arsenic & $3.01983 \mathrm{E}-02$ \\
\hline INEL & 01 & - & $\mathrm{Ba}$ & barium & $2.76818 \mathrm{E}+00$ \\
\hline INEL & 01 & - & $\mathrm{cd}$ & cadmium & $1.11985 \mathrm{E}-01$ \\
\hline INEL & 01 & - & $\mathrm{cl}-2-\mathrm{x}$ & di-chloro-hydrocarbons & $1.25826 \mathrm{E}-01$ \\
\hline INEL & 01 & - & $\mathrm{c} 1-3-x$ & tri-chloro-hydrocarbons & $2.64235 \mathrm{E}-01$ \\
\hline INEL & 01 & - & $\mathrm{Cl} 1-4-\mathrm{x}$ & tetra-chloro-hydrocarbons & $7.54958 \mathrm{E}-01$ \\
\hline INEL & 01 & - & $\mathrm{Cl}-\mathrm{F}-\mathrm{x}$ & chloro-fluoro-hydrocarbons & $6.29131 \mathrm{E}-02$ \\
\hline INEL & 01 & - & $\mathrm{Cr}$ & chromium & $4.90722 \mathrm{E}+00$ \\
\hline INEL & 01 & - & HC-insolub & benzene, toluene, xylene & $7.54958 \mathrm{E}-03$ \\
\hline INEL & 01 & - & HC-soluble & acetone, butanone, methanol & $6.92045 E+02$ \\
\hline INEL & 01 & - & $\mathrm{Hg}$ & mercury & $2.51652 \mathbf{E}-0.3$ \\
\hline INEL & 01 & - & $\mathrm{Pb}$ & lead & $1.38409 \mathrm{E}+00$ \\
\hline INEL & 01 & - & Se & selenium & $7.54958 \mathrm{E}-02$ \\
\hline
\end{tabular}

These data are repeated for each treatability category and site. For both LLMW and TRUW, the chemical profiles for a given treatability category are assumed to be the same at every site.

These data are repeated for each treatability

category and site. Except for LLW, it is assumed

have the same radiological profile. 


\subsection{TSD FACILITY CHARACTERIZATION}

Treatment technologies are described by partitioning coefficients for distributing input waste load volumes and masses among one or more output waste streams. The partitioning coefficients for waste contaminants describe the movement of contaminants among the several output streams, including air releases, and may include the destruction of organic compounds. The TSD technologies can include process technologies such as packaging and incineration, as well as waste storage, treated waste disposal, or treated water discharge. The technology modules applied to the waste streams are described in Tables 4 , 5, and 6. Each table contains entries that are specific for each waste type (e.g., LLW or LLMW) and waste treatability. The table entries illustrate the incineration parameters for LLMW treatability category 05, halogenated organic liquids. (For LLMW, the term "treatment code" is used in Appendix L of DOE [1995] to describe treatability category.)

Table 4, from the file TCH_PRAM, contains partitioning coefficients for the bulk parameters:

- Volume concentration or expansion of product output stream (in this case, ash) relative to input volume;

- Mass fraction of product stream relative to input mass;

- Mass fractions of secondary output streams (called residuals) relative to input mass; and

- Densities of secondary output streams.

In the current model, process inputs such as fuel, water, and process additives are not explicitly incorporated in the computations. However, these factors are utilized implicitly in the solidification treatments by product volume concentrations and product mass fractions greater than unity. For technologies such as packaging or disposal, the treatment parameters are not specific to the treatability of the waste stream. Other technologies that are highly dependent upon the composition of the stream, such as incineration, include entries for each waste treatability category that uses the treatment.

Tables 5 and 6 illustrate the fractional partitioning of the radiological contaminants (from file REL_FRAC) and hazardous contaminants (from file REL_CHEM) among the output streams and a release to the atmosphere. The computation for the distribution of hazardous contaminants can also account for the destructive removal or neutralization of contaminants. For example, when organic contaminants are destroyed in incineration, the sum of partitioning coefficients of organic contaminants for the output streams is less than unity - that is, the coefficients are the fractions of input contaminants that remain after incineration. In Table 6, the fraction of contaminants destroyed is shown under the column "Destroy." 
TABLL \& TCH_PRAM, Treatment, storage, and Disposal Facility Characterization

\begin{tabular}{|c|c|c|c|c|c|c|c|c|c|c|c|c|c|c|}
\hline Waste & Type: LLMW & & & & & Module $\mathrm{T}$ & hnology $\mathrm{ch}$ & acterizat & & & & & & \\
\hline \multirow[b]{2}{*}{$\begin{array}{l}\text { Tech } \\
\text { Cade }\end{array}$} & \multirow[b]{2}{*}{ Technology } & \multirow[b]{2}{*}{$\begin{array}{l}\text { Treatability } \\
\text { Code }\end{array}$} & \multicolumn{2}{|c|}{ Liquid } & \multicolumn{2}{|c|}{ Solids } & \multicolumn{2}{|c|}{ Salt } & \multicolumn{2}{|c|}{ Debris } & \multicolumn{2}{|c|}{ Mercury } & \multicolumn{2}{|c|}{$\begin{array}{c}\text { Product } \\
\text { Concentration }\end{array}$} \\
\hline & & & $\begin{array}{l}\text { Residual } \\
\text { Fraction }\end{array}$ & $\begin{array}{l}\text { Density } \\
(\mathrm{kg} / \mathrm{m} 3)\end{array}$ & $\begin{array}{l}\text { Residual } \\
\text { Fraction }\end{array}$ & $\begin{array}{l}\text { Density } \\
(\mathrm{kg} / \mathrm{m} 3)\end{array}$ & $\begin{array}{l}\text { Residual } \\
\text { Fraction }\end{array}$ & $\begin{array}{l}\text { Density } \\
(\mathrm{kg} / \mathrm{m} 3)\end{array}$ & $\begin{array}{l}\text { Residual } \\
\text { Fraction }\end{array}$ & $\begin{array}{l}\text { Density } \\
(\mathrm{kg} / \mathrm{m} 3)\end{array}$ & $\begin{array}{l}\text { Residual } \\
\text { Fraction }\end{array}$ & $\begin{array}{l}\text { Density } \\
(\mathrm{kg} / \mathrm{m} 3)\end{array}$ & $\begin{array}{l}\text { Volume } \\
\text { Factor }\end{array}$ & $\begin{array}{l}\text { Mass } \\
\text { Factor }\end{array}$ \\
\hline 1 & INCINERATION & 05 & $6.473 E-01$ & $1.953 \mathrm{E}+03$ & & . & . & & . & . & $1.267 \mathrm{E}-03$ & $1.354 \mathrm{E}+04$ & $1.015 \mathrm{E}-01$ & $1.186 \mathrm{E}$ \\
\hline
\end{tabular}

The data in this file are arranged by technology and for some technologies by treatability category. (See text for explanation.)

TABIS 5 REL_FrAC: TED Radiological Partitioning Confficionte

\begin{tabular}{|c|c|c|c|c|c|c|c|c|c|c|}
\hline Waste & e Type: ILMW & Release & ractions & Activity as & s Function of & f Input (C: & out $] / C i[$ in & & & \\
\hline Code & Technology & Treatability & Nuclide & Air_res & Liquid_res & Solid_res & salt_res & Debris_res & Hg_res & Product \\
\hline 1 & INCINERATI ION & 05 & All oth & $4.7134 \mathrm{E}-06$ & $5.2613 \mathrm{E}-02$ & . & & - & $1.0297 \mathrm{E}-04$ & $9.4727 \mathrm{E}-01$ \\
\hline & INCINERATION & 05 & & $9.8300 \mathrm{E}-01$ & $9.9971 \mathrm{E}-04$ & . & & . & $2.8226 \mathrm{E}-07$ & $1.6000 \mathrm{E}-02$ \\
\hline 1 & $\begin{array}{l}\text { INCINERATION } \\
\text { TNCINERATION }\end{array}$ & $\begin{array}{l}05 \\
05\end{array}$ & As & $\begin{array}{l}4.6300 \mathrm{E}-08 \\
1.1700 \mathrm{E}-07\end{array}$ & $\begin{array}{r}9.9804 \mathrm{E}-02 \\
1.0000 \mathrm{E}-02\end{array}$ & 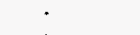 & • & - & $\begin{array}{l}1.9534 \mathrm{E}-04 \\
9.7999 \mathrm{E}-01\end{array}$ & $\begin{array}{r}8.9999 \mathrm{E}-01 \\
\end{array}$ \\
\hline
\end{tabular}

The data in this file are arranged by technology and for some technologies by treatability category. (See text for explanation.)

TABLz 6 REL_CHEMs TSD Hazardous Contaminant Partitioning Coofficient:

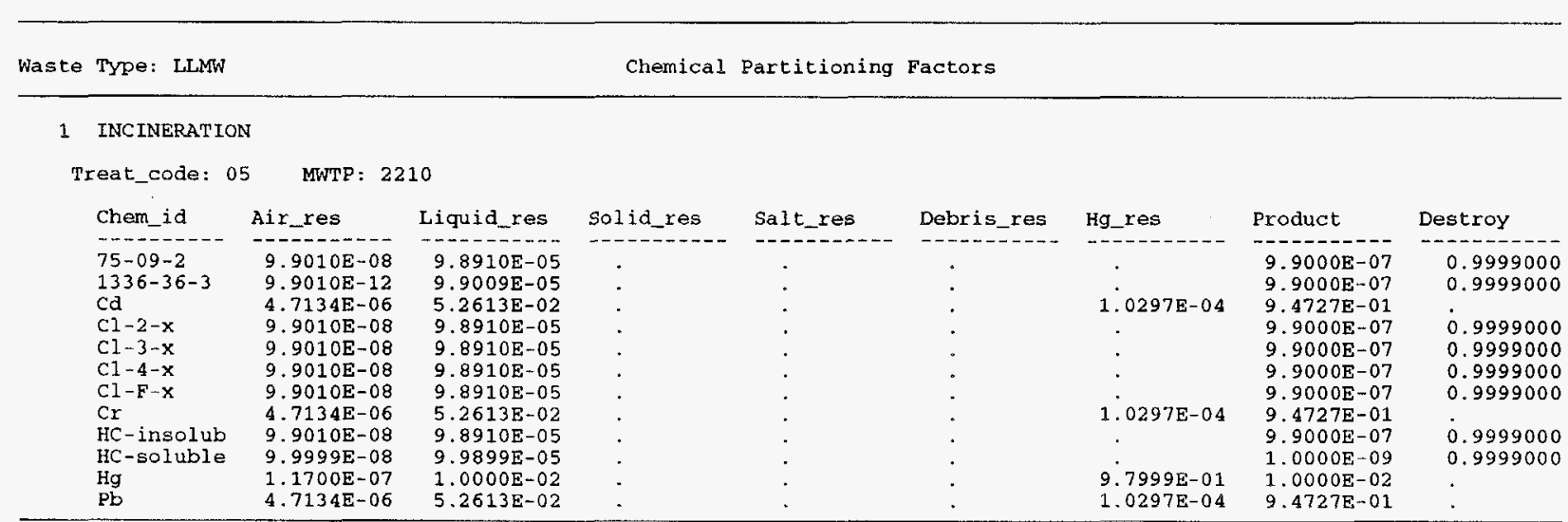
The data in this file are arranged by technology and for some technologies by treatability category. (See text
for explanation.) 


\subsection{ALTERNATIVE DEFINITION}

The processing alternative definition describes the sequence of treatment technologies to be applied and the treatment and disposal locations of each inventory waste stream. The processing alternatives are defined in a single table that describes the sequence of TSD modules to be applied to the waste streams, as well as the originating site, treatment site, and disposal site. Each waste stream, by treatability and handling characteristic, at a generating site will be represented by one record or several records that specify the sequence of modules entered to arrive at a final form output, either solidified treated waste, grout, or treated wastewater discharge. Each unique secondary output stream encountered in the treatment sequence will have one record and final form component. In the current model, two pretreatments can be specified at the generating site, followed by as many as six treatments at the treatment site, and completed with the disposal option at the disposal site. A unique number was assigned to each WM PEIS case by waste type, and this alternative number was used to generate unique output file names. (See the Appendix for a description of alternative number assignments.) Table 7 provides the table entries from file ALTERNTS that illustrate the treatment train for processing LLMW treatability category 01 , aqueous liquids. Similar, but less complex, table entries for the processing of LLW combustible waste are shown in Table 8 (and Figure 1) and are described in Section 3. 


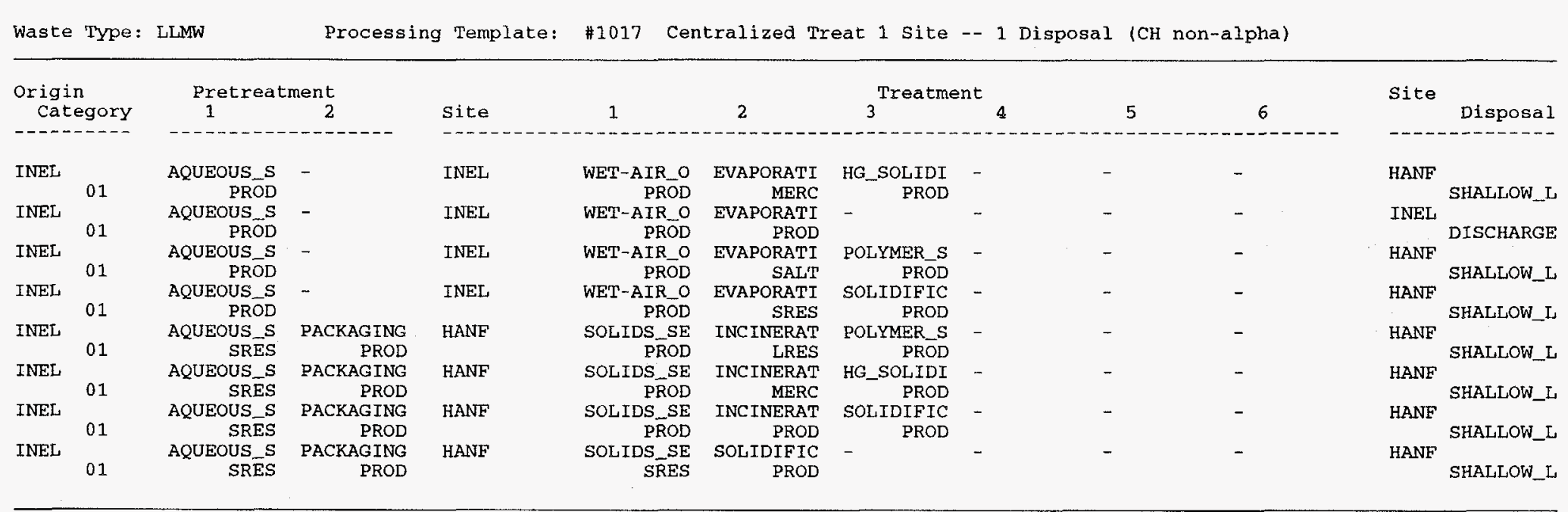

These data are provided for each treatability category at each generating site.

Nomenclature for Table 7:
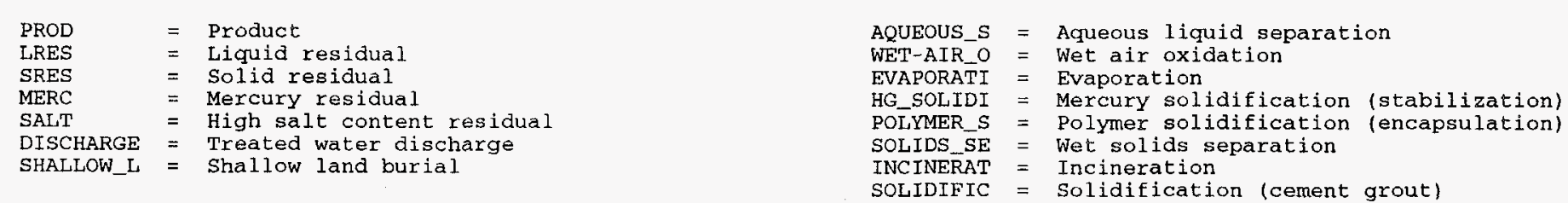
TABLB 8 Alternative Definition of a Treatment Train for a LLW Waste stream

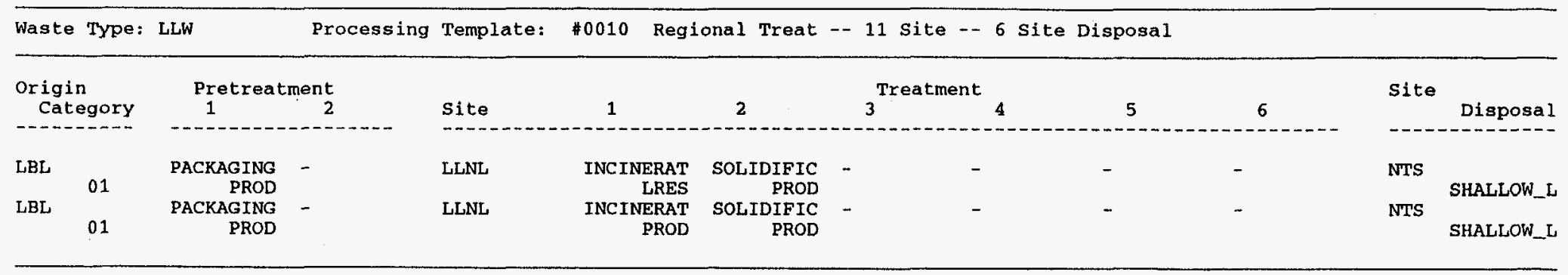

These data are provided for each treatability category at each generating site.

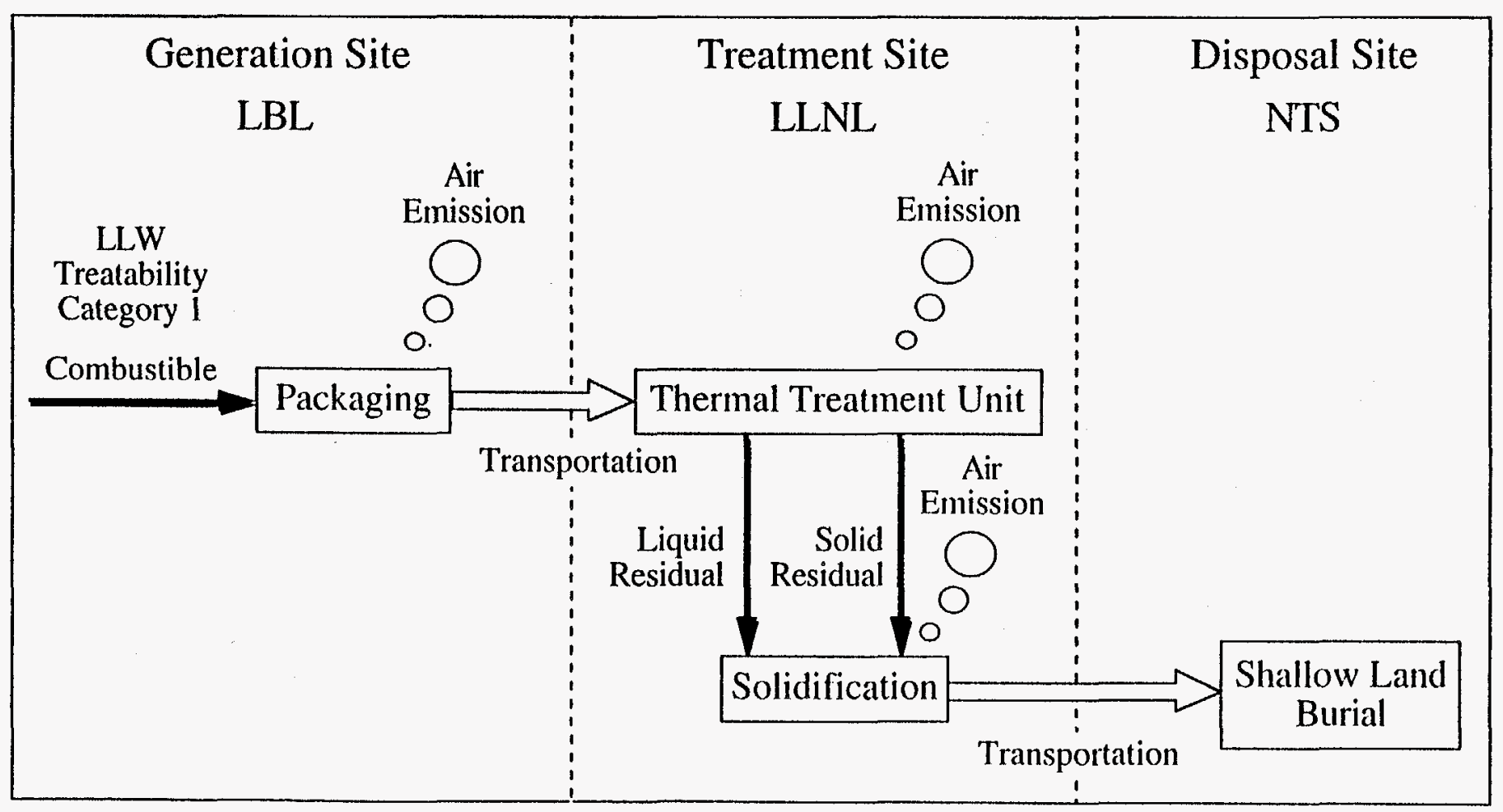

FIGURE 1 Schematic of a Treatment Train for a LLW Waste Stream 


\section{DESCRIPTION OF THE MODEL}

\subsection{FUNCTIONAL DESCRIPTION}

The model computations are applied for each entry in the alternative table, Table 8 , by stepping through first the pretreatment technologies at the generating site, followed by the treatment technologies at the treatment site, and ending with the disposal technology at the disposal site. For each treatment step, the computation proceeds as follows:

- Step i: the current substream (any secondary, tertiary, etc., output stream resulting from a distinct treatment sequence) volume, mass, and contaminant profiles - similar to parameters shown in Tables 1,2 , and 3 - are written to a set of cumulative output files when the technology is first encountered for a given input substream;

- Step ii: the contaminant air releases associated with the technology are computed once for the input substream using Tables 5 and 6 ; and,

- Step iii: the technology partitioning coefficients - Tables 4, 5, and 6are applied to the waste volume, mass, and contaminant profiles for the output stream specified by that step, and a new set of table entries for that output stream is propagated as input to the next treatment processing step.

In this manner, all secondary output streams defined for the treatment train result in a unique set of entries in the primary output files.

A treatment train is shown schematically for LLW incineration of combustible material in Figure 1. With reference to Figure 1 and Table 8, the progression through a treatment train may be explained as follows:

1. In the first pretreatment, the waste inventory volume and mass throughput rates and profiles are presented to the PACKAGING module at the generation site, Lawrence Berkeley National Laboratory (LBL) (Step i). The air release associated with waste handling during this operation is computed using the corresponding AIR_RES coefficient for LLW and the PACKAGING technology in REL_FRAC (Step ii). Entries are made in the primary output files that identify the original inventory waste stream and the current stage of the treatment train. These entries are described below.

2. The waste inventory and profile for the product output stream (PROD) are computed using the corresponding entries in TCH_PRAM and REL_FRAC (REL_CHEM is not needed for LLW). The volume, mass, and contaminant profile of the input substream are transformed using 
the TSD partitioning coefficients to obtain the waste characterization of the output stream (Step iii).

3. Because a second pretreatment is not specified, the next treatment is INCINERATION at the treatment site, Lawrence Livermore National Laboratory (LLNL). Steps i, ii, and iii are repeated using the PROD output from the PACKAGING module and the TSD coefficients for INCINERATION. The liquid residual (LRES) from the incineration off-gas scrubber is the LRES secondary output stream.

4. The LRES output from INCINERATION is sent to SOLIDIFICATION, and Steps i, ii, and iii are repeated using the TSD coefficients for SOLIDIFICATION.

5. No other treatments are necessary, and the PROD output from SOLIDIFICATION is sent to the disposal site, Nevada Test Site (NTS). Steps $i$ and ii are applied using as the TSD module the disposal option SHALLOW_LAND_BURIAL.

6. The next record in the alternative definitive has identical entries except that the output stream of the first treatment, INCINERATION, is PROD, not LRES. The identical entries are skipped, and the processing continues by repeating Step iii for the PROD output stream of INCINERATION, which is ash.

7. The PROD output from INCINERATION is sent to SOLIDIFICATION, and Steps i, ii, and iii are repeated using the TSD coefficients for SOLIDIFICATION.

8. No other treatments are necessary, and the PROD output from SOLIDIFICATION is sent to the disposal site, NTS. Steps $i$ and ii are applied using the disposal option SHALLOW_LAND_BURIAL as the TSD module.

\subsection{IMPLEMENTATION}

The model is implemented in Microsoft ${ }^{\circledR}$ FoxPro $^{\circledR} 2.5$ for MS-DOS ${ }^{\circledR}$, extended version, and consists of approximately 4200 lines of FoxPro ${ }^{\circledR}$ code with comments. An additional 2800 lines of code were written for preparation of the model's base tables. The current implementation using a 386DX processor with 6 Mbytes RAM required 10 to 30 minutes to process each of the relatively simple LLW alternatives. The more complex TRUW and LLMW cases were run on a microcomputer with at least a $50-\mathrm{MHz} 486 \mathrm{DX} 2$ processor with 16 Mbytes RAM. The running times for these complex cases varied from 30 minutes for the least complex to over 4 hours for the worst cases. Running the code on 60 and $90 \mathrm{MHz} \mathrm{INTEL}^{\circledR}$ Pentium $^{\mathrm{TM}}$ processors reduced the running times by factors of 2 to 3 . Disk storage for the 
model's source code, executables, and report forms is approximately 1 Mbyte; the model base tables and input tables for the LLW, ER-LLW, LLMW, ER-LLMW, TRUW, and ER-TRUW waste types require 7.65 Mbytes. 


\section{DESCRIPTION OF MODEL OUTPUT}

The primary output of the model consists of five tables that contain entries for each unique substream path traversed from the initial input until the final waste form is disposed or discharged. Tables 9 and 10 show portions of the output records that correspond to the LLW treatment train illustrated in Figure 1. The entries in Table 9, file THRT, contain the volume and mass of the waste substreams that are input to each TSD module and, in addition, include identifying values for the specific inventory stream (waste type, generating site, handling characteristic, and treatability), substream path (previous site, previous TSD module, previous TSD output), and current stage of processing (current site, current TSD module).

Corresponding entries in Table 10, file THRN, contain the radiological profiles for the specific substreams. Air releases of radionuclides associated with the TSD modules are made in file AIRN, also shown in Table 10 for this example. For waste types that have hazardous contaminants, two additional files are generated: THRC contains the hazardous contaminant profiles of the specific waste substreams and AIRC contains the air releases of hazardous contaminants associated with the TSD modules. Examples of these are shown for LLMW in Table 11.

Common fields link the associated entries in files THRT, THRN, and THRC. The entries in the linking fields form unique keys that identify specific substreams in the treatment train. In the examples shown, the table entries labeled "Treatment Train" are constructed by the model at each treatment step to record the history of substreams. This field - with the generating site, handling characteristic, and treatability category uniquely identifies each substream generated during the treatment train for a given alternative.

The level of detail that is preserved in these primary output files enables great flexibility in the generation of summary reports. This detail also provides the ability to postprocess the results by scaling specific parameters and then reproducing the summary reports without rerunning the model. In general, the source terms produced by the WASTE_MGMT model will be summarizations of the primary output files. Examples of these are discussed in Section 5. A glossary of WASTE_MGMT files, including additional summary files, is presented in the Appendix. 
TABLE 9 THRT: WASTE_MGMT Substream Throughput

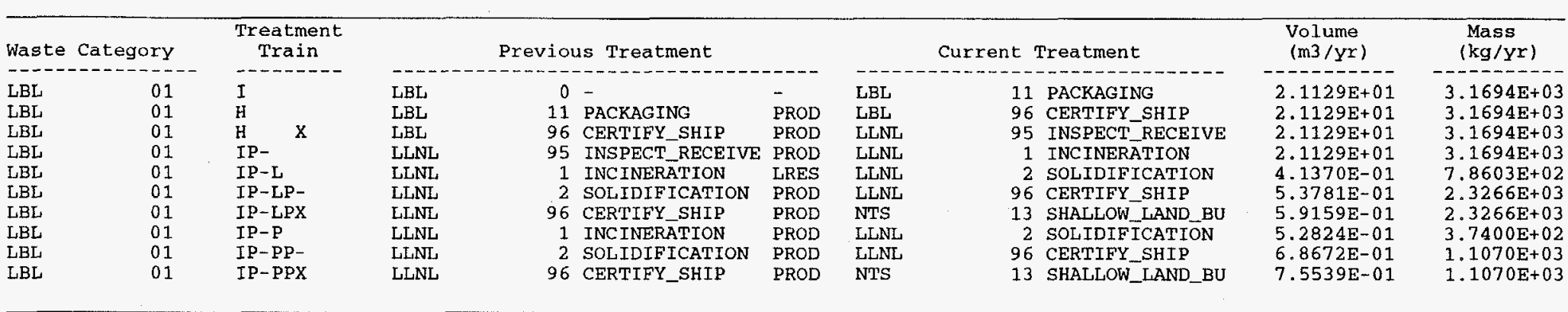

This table contains throughput values for each substream path specified by the treatment train and for each waste inventory item by generating site, handling characteristic, and treatability. Table entries "Treatment Train" are constructed by the model at each treatment step to uniquely identify each substream generated during the treatment train.

TABLE 10 THRN and AIRN: WASTE_MGMT Substream Radiological Profile and Releases

Waste Stream: LLW

\begin{tabular}{lllclccc}
\hline Waste Category & $\begin{array}{c}\text { Treatment } \\
\text { Train }\end{array}$ & Previous Treatment & & Activity & Air Release \\
(Ci/Yr)
\end{tabular}

This table contains radiological profiles for each substream path specified by the treatment train and for each waste inventory it by generating site, handing characteris for each substreat path specifled by the treatment train and for each waste inventory item contains entries for each radionuclide in the waste stream. "Treatment Train" links corresponding records in THRT (Table 9 ) 


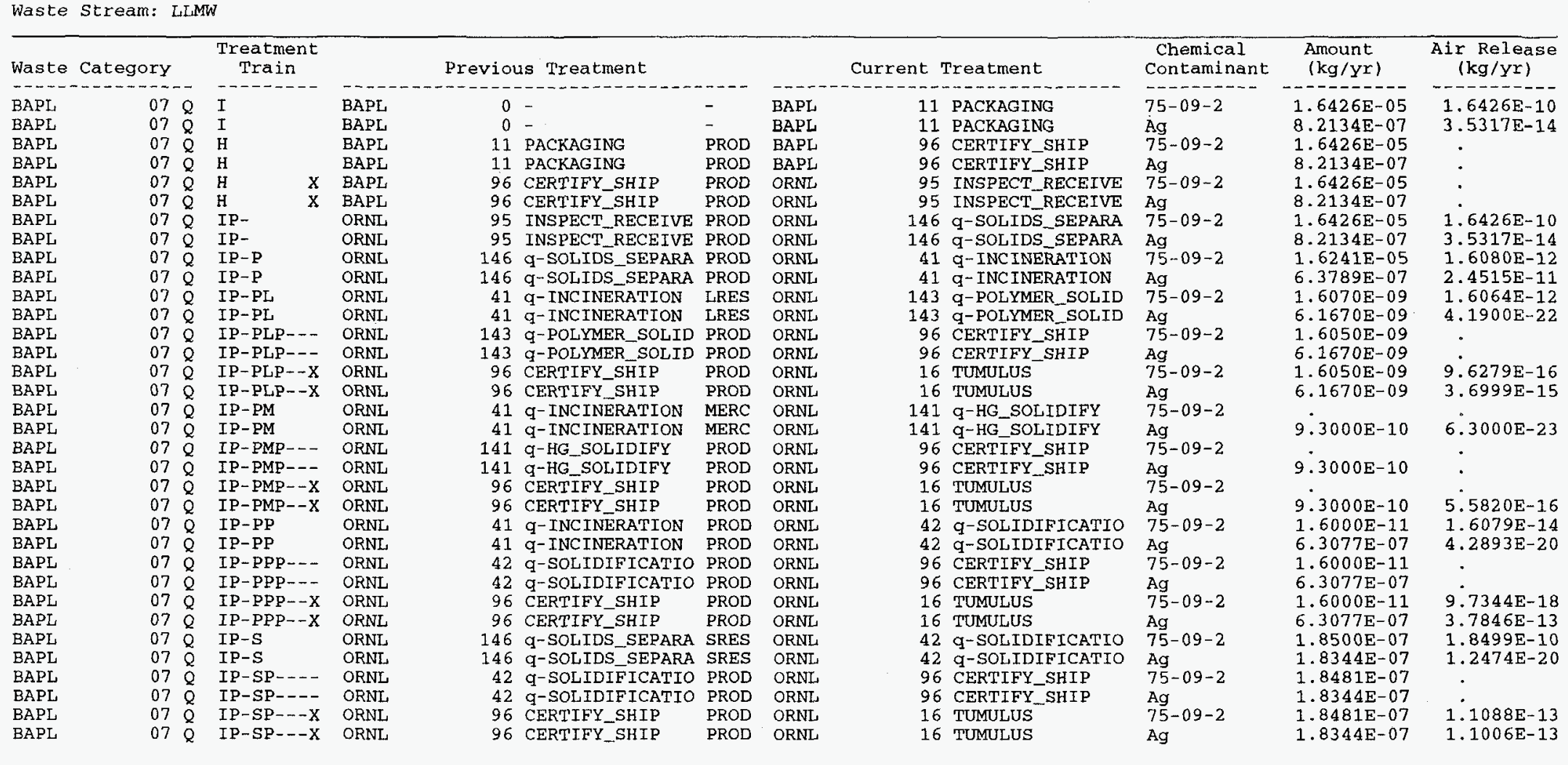

This table contains hazardous contaminant profiles for each substream path specified by the treatment train and for each waste inventory The actual file contains entries for each contaminant in the waste stream. "Treatment Train" links corresponding records in file THRT. 


\section{APPLICATION OF THE WASTE_MGMT MODEL}

The WASTE_MGMT model has been applied for the WM PEIS for waste types LLW, LLMW, and TRUW. Approximately 50 sites have current or projected LLW or LLMW inventories, and approximately 15 sites have TRUW inventories. The source terms generated by the model were distributed as input to analyses by other participants in the WM PEIS. Examples of the data summaries developed for these are as follows.

For LLW, the waste inventory and characterization file and the TSD module characterization file were prepared by ANL-E. Thirty cases for WM-LLW were defined by META/Berger in association with DOE for evaluation in WM PEIS. In addition, six of these cases were also applied to ER-LLW. The data used in the analysis and the output data generated by WASTE_MGMT are provided in Appendix K of the WM PEIS (DOE 1995) and in Goyette (1995).

For LLMW, the waste inventories and generation rates were obtained from the Mixed Waste Inventory Report, Phase II (MWIR-2), as summarized by Palmer at LANL (Palmer 1995). Approximate methods were developed by ANL-E to characterize the radiological and chemical profiles of the wastes. The unit operating parameters for characterization of the TSD modules were developed by ANL-E using the TSD volume partitioning defined for treatment process flow charts supplied by Musgrave (1995). Eleven WM-LLMW cases were processed for evaluation in the WM PEIS, including three cases for PCB-contaminated waste. Five of these cases were also run for ER-LLMW. The data used in the analysis are provided in Appendix L of the WM PEIS (DOE 1995) and in Wilkins et al. (1995).

For TRUW, the waste inventories and generation rates were obtained from the Mixed Waste Inventory Report, Phase I (MWIR-1), as summarized by Palmer in consultation with Hong at ANL-E (Palmer 1995). The treatment process flow charts developed by the Mixed Waste Treatment Project (MWTP) were used to define the treatment trains (Musgrave 1995). Waste contaminant profiles were characterized by ANL-E using the same methods as for LLMW. The unit operations parameters for characterization of the TSD modules were developed by ANL-E in consultation with MWTP staff. Source terms were generated for 15 TRUW cases. Five of these cases were also run for ER-TRUW. The data used in the analysis are provided in Appendix M of the WM PEIS (DOE 1995) and in Hong et al. (1995).

\subsection{DATA DISTRIBUTIONS}

The data distributions from the model applications are as follows:

1. Air emissions during normal operations and throughput values have been provided to Oak Ridge National Laboratory (ORNL) for calculation of radiological doses and health effects to workers and the general 
public. Table 12 contains the database file structures of the throughput and contaminant profile results summarized by treatment site, by TSD module, and by handling characteristic and treatability of the waste. Table 13 shows an example of the radiological and hazardous contaminant air releases summarized by site. The underlying summary database files for these tables were transmitted to ORNL.

2. Throughput quantities were provided to EG\&G Idaho for calculation of TSD module costs and worker populations. EG\&G also calculates the resource requirements for construction of new modules and for the operation of all modules. EG\&G provides the worker population information to ORNL for collective worker dose calculations. An example of the summarized throughput by treatment site, by technology, and by handling characteristic and treatability is shown in Table 14.

3. The quantities and characteristics of the waste shipped between sites were provided to the transportation risk assessment group at ANL-E for calculation of radiological doses and health effects to transportation workers and the general public along the transportation routes. Impacts from both incident-free transport and probable transportation accidents were calculated. Health effects were also calculated for the transportation of hazardous contaminants in the waste. Table 15 is an example of the transported waste summarized by shipping and destination site. The transportation data generated for LLW, LLMW, and TRUW by WASTE_MGMT for the WM PEIS are listed in reports by Monette et al. $(1995 \mathrm{a}-\mathrm{c})$.

4. Throughput quantities and characteristics were provided to the accident analysis group at ANL-E for estimation of air emissions of radionuclides and hazardous contaminants during postulated TSD facility accidents. These accident emissions were then forwarded to ORNL for calculation of worker and general public doses and health effects. The primary output files of the model were used to identify and to group waste substreams that have common physical characteristics. For example, liquid organic waste occurs as an inventory waste stream but can also be generated during the waste treatment train as a secondary output from a TSD module. In Table 16, the input streams to incineration have been combined into larger groups that characterize the physical form of the waste. Category 81, Organic_Liquid_Intermediate, was defined to include both LLMW treatability categories $03,04,05$, and 06, and liquid residual substreams that are sent for incineration, for example, the liquid residual from thermal desorption. The accident analyses using source terms generated by WASTE_MGMT are reported in Mueller et al. (1995). 
TABLE 12 Data Structures: Throughput and profile by Site, Technology, and Treatability

TRTTnnnn.DBF contains the throughput volume and mass by treatment site, handing characteristic, technology, and treatability category. "nnnn" is the alternative number assigned to create unique file names.

\section{Field Field Name Type}

$\begin{array}{lll}\text { ALT_NUMBER } & \text { Numeric } & \text { alternative number } \\ \text { WASTE_STR } & \text { Character } & \text { waste stream } \\ \text { SITE } & \text { Character } & \text { treatment site } \\ \text { ALPHA_TRT } & \text { Character } & \text { waste handling } \\ \text { TECH_CODE } & \text { Numeric } & \text { technology code } \\ \text { TREAT_CODE } & \text { Character } & \text { treatability code } \\ \text { THRU_VOI } & \text { Numeric } & \text { thruput volume }(\mathrm{m} 3 / \mathrm{Yr}) \\ \text { THRU_MASS } & \text { Numeric } & \text { thruput mass }(\mathrm{kg} / \mathrm{Yr})\end{array}$

TRTNnnnn.DBF contains the radionuclide distribution and air release by treatment site, handling characteristic, technology, and treatability category. please note that the unit for air releases is nanocuries per year.

$\begin{array}{rll}\text { Field } & \text { Field_Name } & \text { Type } \\ 1 & \text { ALT_NUMBER } & \text { Numeric } \\ 2 & \text { WASTE_STR } & \text { Character } \\ 3 & \text { SITE } & \text { Character } \\ 4 & \text { ALPHA_TRT } & \text { Character } \\ 5 & \text { TECH_CODE } & \text { Numeric } \\ 6 & \text { TREAT_CODE } & \text { Character } \\ 7 & \text { NUCLIDE } & \text { Character } \\ 8 & \text { ATOMIC_NO } & \text { Numeric } \\ 9 & \text { TOT_ACT } & \text { Numeric } \\ 10 & \text { AIR_RF } & \text { Numeric }\end{array}$

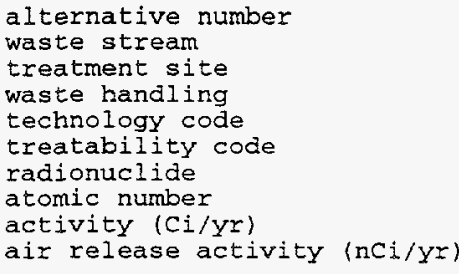

TRTCnnn.DBF contains the chemical distribution and air release by treatment site, handing characteristic, technology, and treatability category. Please note that the unit for air releases is micrograms per year.

$\begin{array}{rlll}\text { Field } & \text { Field Name } & \text { Type } & \\ 1 & \text { ALT_NUMBER } & \text { Numeric } & \text { alternative number } \\ 2 & \text { WASTE_STR } & \text { Character } & \text { waste stream } \\ 3 & \text { SITE } & \text { Character } & \text { treatment site } \\ 4 & \text { ALPHA_TRT } & \text { Character } & \text { waste handing } \\ 5 & \text { TECH_CODE } & \text { Numeric } & \text { technologY code } \\ 6 & \text { TREAT_CODE } & \text { Character } & \text { treatability code } \\ 7 & \text { CHEM_ID } & \text { Character } & \text { chemical contaminant } \\ 8 & \text { CHEM_AMT } & \text { Numeric } & \text { amount (kg/Yr) } \\ 9 & \text { CHEM_RF } & \text { Numeric } & \text { air release }(\mu g / \mathrm{yr})\end{array}$

For each WM PEIS case, the above files contain a summary of the waste throughput, contaminant profiles, and air releases. Entries will appear for each generating site, treatment site, and disposal site and for each treatment technology and treatability category that are included in the given alternative. 
TABLE 13 Radiological and Hazardoug Contaminant Air Releases by site

Radionuclide Thruput and Air Release by Site

Alternative: \#10 Regional Treat -- 11 Site -- 6 Site Disposal

Waste Stream: LLW

Treatment Site: LBL

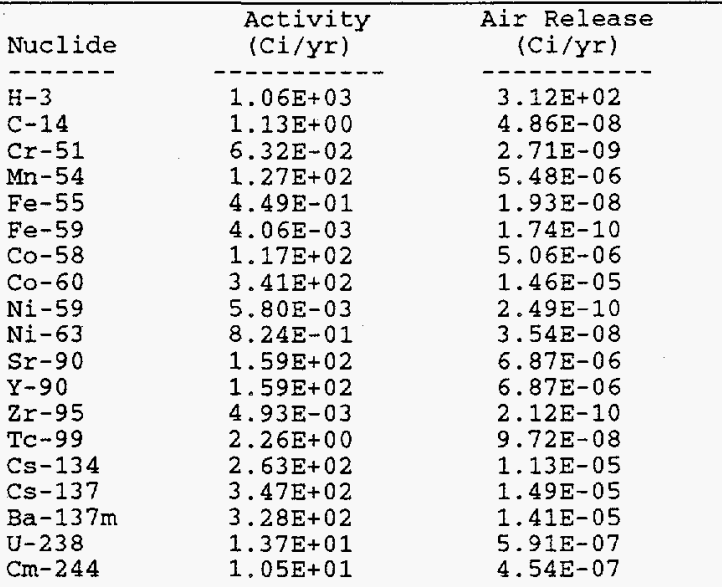

Chemical Thruput and Air Release by Site

Alternative: \#1026 Remote Handle - Treat 4 Sites -- 4 Disposal

Waste Stream: LLMW

Treatment Site: BAPL Waste Handling: RH_non-alpha

\begin{tabular}{llcc}
\hline & Chemical contaminant & $\begin{array}{c}\text { Amount } \\
(\mathrm{kg} / \mathrm{Yr})\end{array}$ & $\begin{array}{c}\text { Air Release } \\
(\mathrm{kg} / \mathrm{Yr})\end{array}$ \\
$75-09-2$ & methylene chloride & $-1.64 \mathrm{E}-05$ & $1.64 \mathrm{E}-10$ \\
$\mathrm{Ag}$ & silver & $8.21 \mathrm{E}-07$ & $3.53 \mathrm{E}-14$ \\
$\mathrm{As}$ & arsenic & $6.81 \mathrm{E}-07$ & $2.93 \mathrm{E}-14$ \\
$\mathrm{Ba}$ & barium & $2.13 \mathrm{E}-05$ & $9.18 \mathrm{E}-13$ \\
$\mathrm{Cd}$ & cadmium & $9.85 \mathrm{E}-06$ & $4.23 \mathrm{E}-13$ \\
$\mathrm{Cl}-2-\mathrm{x}$ & di-chloro-hydrocarbons & $1.64 \mathrm{E}-05$ & $1.54 \mathrm{E}-10$ \\
Cl-3-x & tri-chloro-hydrocarbo & $9.85 \mathrm{E}-04$ & $9.85 \mathrm{E}-09$ \\
$\mathrm{Cl}-4-\mathrm{x}$ & tetra-chloro-hydrocar & $1.80 \mathrm{E}-04$ & $1.80 \mathrm{E}-09$ \\
$\mathrm{Cl}-\mathrm{F}-\mathrm{x}$ & chloro-fluoro-hydroca & $7.39 \mathrm{E}-06$ & $7.39 \mathrm{E}-11$ \\
$\mathrm{Cr}$ & chromium & $3.69 \mathrm{E}-05$ & $1.58 \mathrm{E}-12$ \\
$\mathrm{HC}-\mathrm{insolub}$ & benzene, toluene, xylen & $3.28 \mathrm{E}-03$ & $3.28 \mathrm{E}-08$ \\
$\mathrm{HC}-\mathrm{soluble}$ & acetone, butanone, meth & $1.64 \mathrm{E}-03$ & $1.64 \mathrm{E}-08$ \\
$\mathrm{Hg}$ & mercury & $1.10 \mathrm{E}-05$ & $4.75 \mathrm{E}-13$ \\
$\mathrm{~Pb}$ & lead & $1.64 \mathrm{E}-05$ & $7.06 \mathrm{E}-13$ \\
$\mathrm{Se}$ & selenium & $2.95 \mathrm{E}-06$ & $1.27 \mathrm{E}-13$ \\
& & & \\
\hline
\end{tabular}

These output tables provide a summary of the contaminant air release by site. They will contain entries for each generating site, treatment site, and disposal site that are included in the given alternative. 
TABLE 14 Throughput and Transportation Summary by Site, Technology, and Treatability

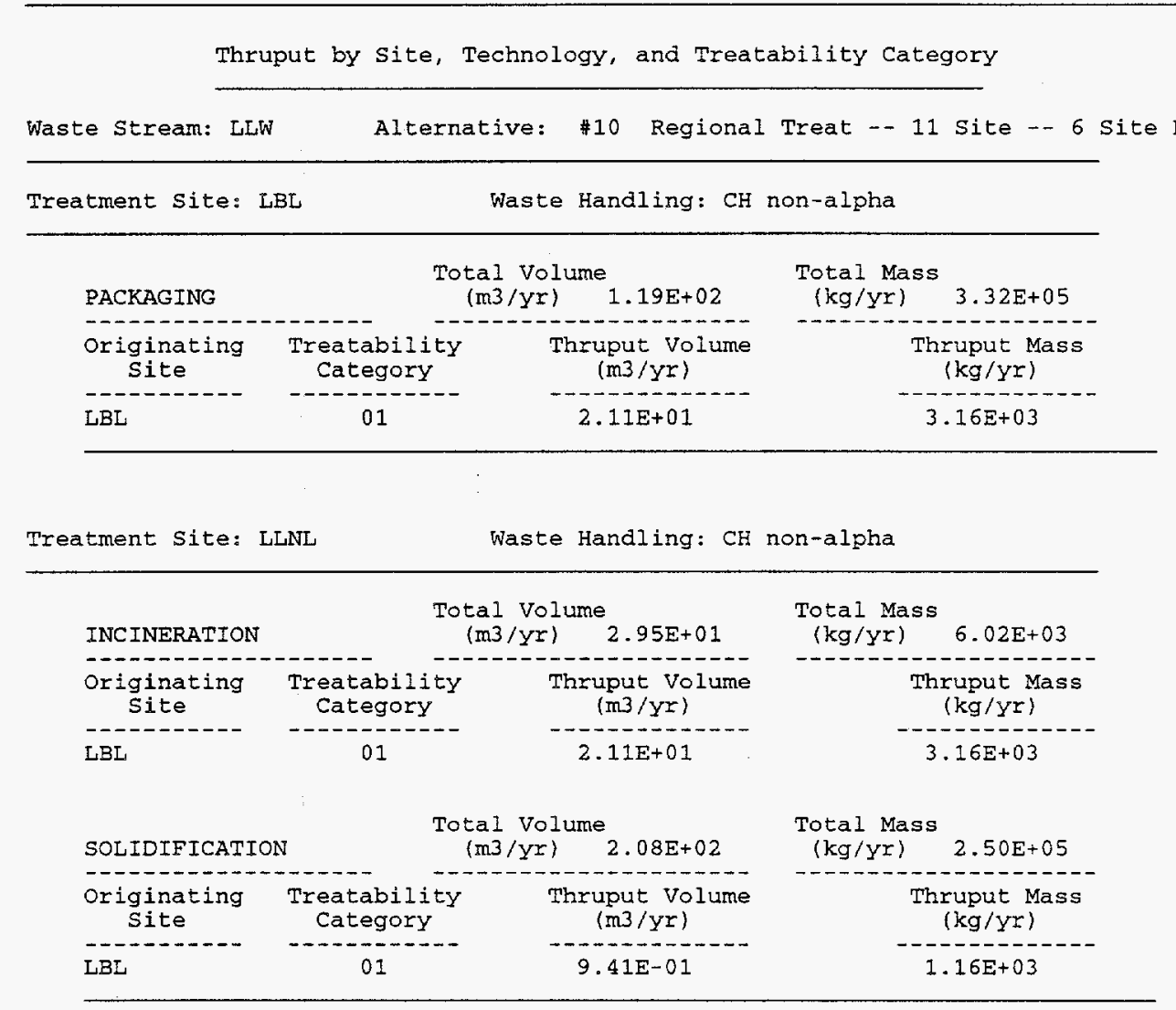

Transported Material by Treatability Category

Waste Stream: LLW Alternative: \#10 Regional Treat -- 11 Site -- 6 Site Disposal

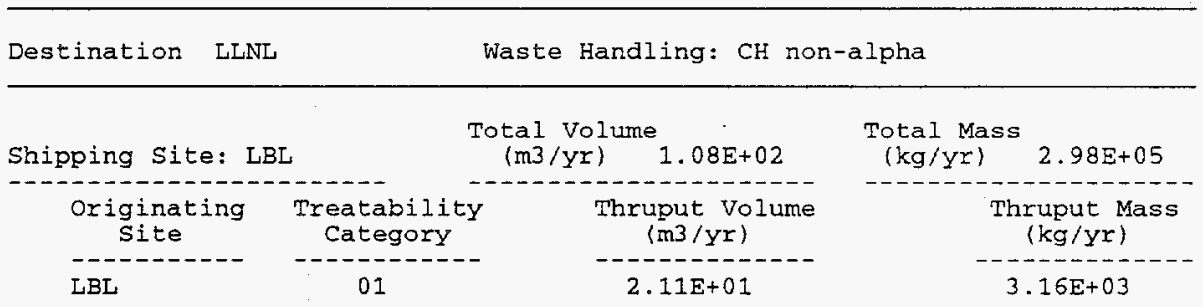

Destination NTS Waste Handling: CH non-alpha

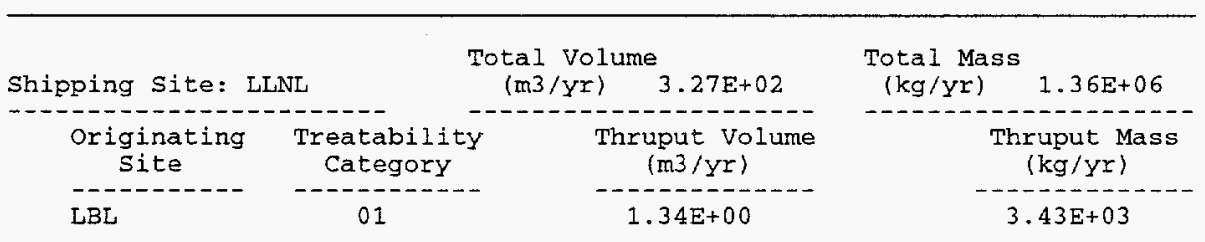

These output tables contain a summary by treatability, of waste throughput and of transported wastes by site. Entries will appear for each generating site, treatment site, and disposal site and for each treatment technology and treatability category that are included in the given alternative. 
TABLE 15 Contaminant Profiles of Transported Wastes

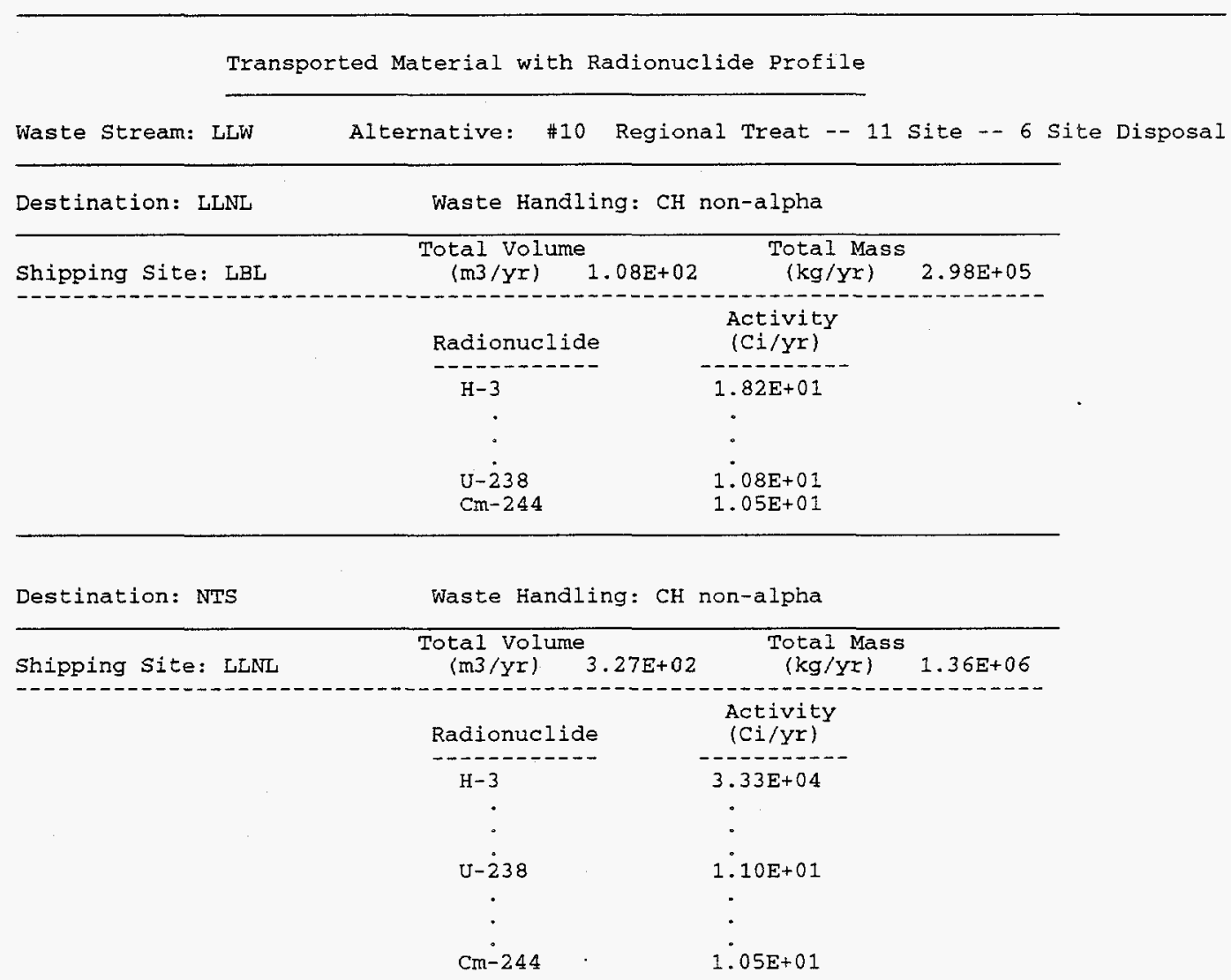

Transported Material with Chemical Profile

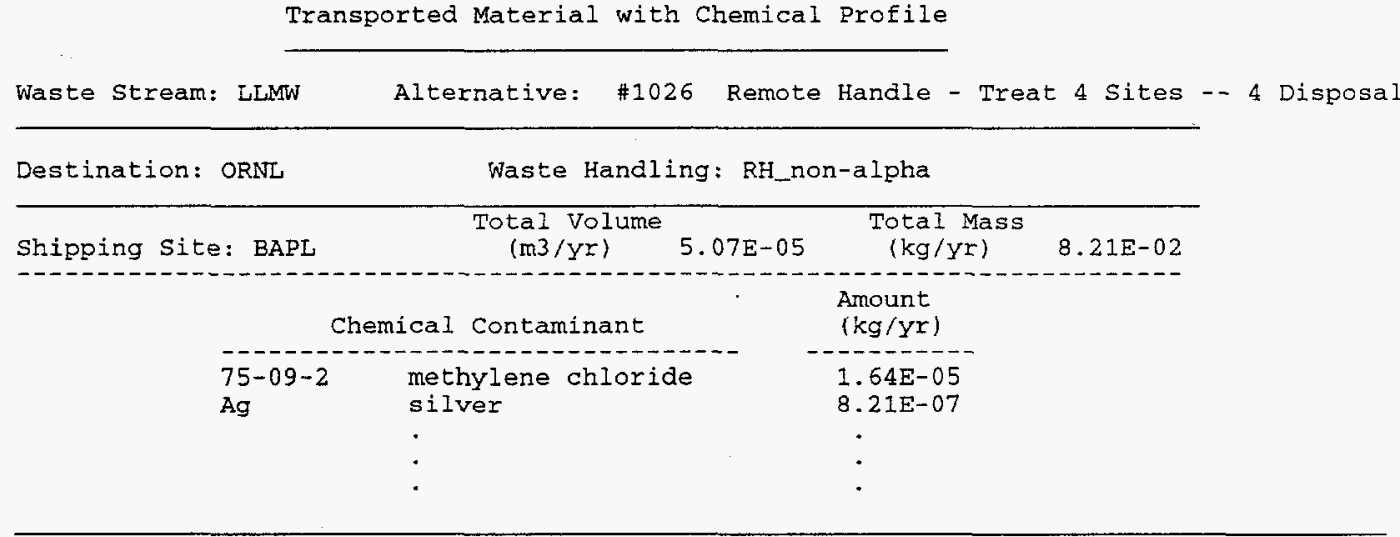

These output tables contain a summary of the transported waste throughput and contaminant profiles. Entries will appear for each pair of shipping and destination sites that are included in the given alternative. 
TABLE 16 Throughput and Contaminant Profiles of Intermediate Substreams

Throughput by Site, Technology and Treatability Category

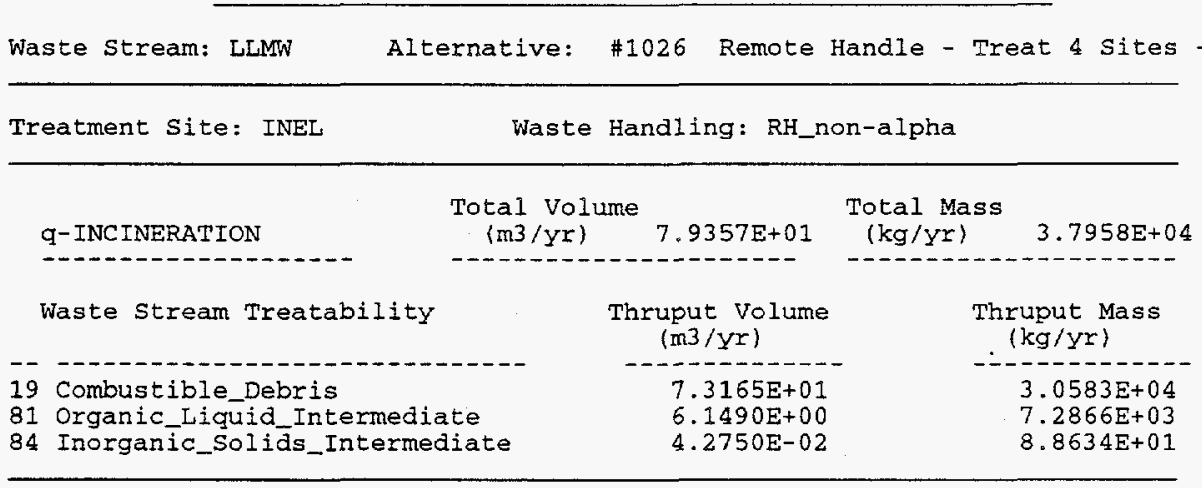

Radionuclide Throughput and Profile by Site and Technology

Waste stream: LLMW Alternative: \#1026 Remote Handle - Treat 4 Sites -- 4 Disposal

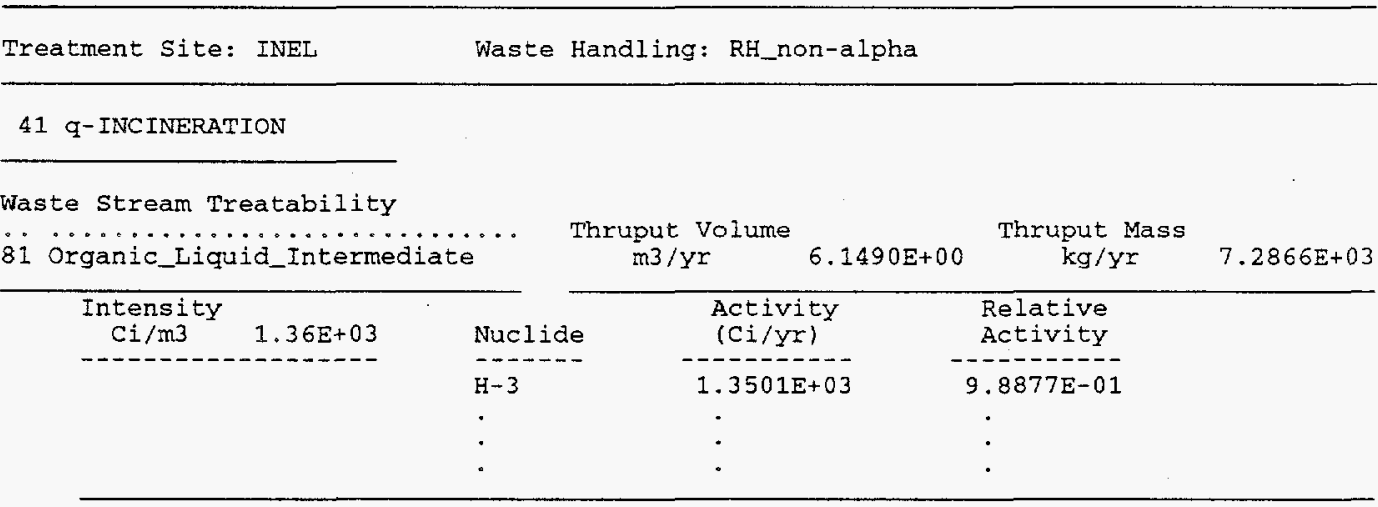

Chemical Throughput and Profile by site and Technology

\begin{tabular}{ll} 
Waste Stream: LLMW Alternative: \#1026 Remote Handle - Treat 4 Sites -- 4 Disposal \\
Treatment Site: INEL $\quad$ Waste Handling: RH_non-alpha \\
\hline
\end{tabular}

41 q-INCINERATION

Waste stream Treatability

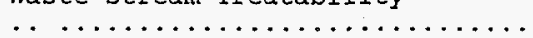

81 Organic_Liquid_Intermediate

Thruput Volume Thruput Mass

$\mathrm{m} 3 / \mathrm{Yr} \quad 6.1490 \mathrm{E}+00 \quad \mathrm{~kg} / \mathrm{yr}^{2} \quad 7.2866 \mathrm{E}+03$

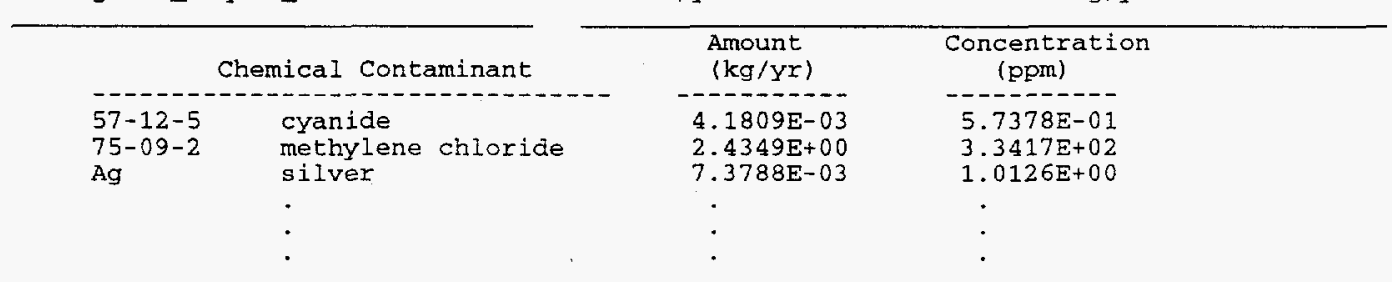

These output tables provide a summary of the throughput and contaminant profiles by site, technology, and intermediate waste physical form. They will contain entries for each treatment site and for technologies of most significant risk as specified by the accident analysis group. 
5. Air emissions and discharges to surface water bodies during normal operations and throughput values have been provided to META/Berger for estimation of air and water quality impacts and the preparation of WM PEIS supporting documentation. Table 17 shows an example of the radiological and hazardous contaminant air releases summarized by treatment site and by TSD module. The underlying summary database files for these tables were transmitted to META/Berger.

\subsection{SUMMARY STATISTICS}

Because the WASTE_MGMT model captures the details of all defined substreams, the running times and storage requirements vary with the complexity of the input waste streams and the treatment trains applied. Similarly, the output storage requirements depend on both the number of input waste streams and the treatment trains. Table 18 illustrates the variability in running times and output file sizes for representative WM PEIS cases of differing waste types. All cases were run on a $90-\mathrm{MHz}$ Pentium ${ }^{\mathrm{TM}}$ processor with $16-\mathrm{Mbyte}$ RAM.

The model has been thoroughly checked and verified by hand calculations for accuracy. However, because of the time constraints of the WM PEIS project, the current version of the code has not been optimized and does not include a user interface other than the FoxPro ${ }^{\circledR}$ environment. The input data for separate WM PEIS cases were organized to permit execution in a batch mode within the FoxPro ${ }^{\circledR}$ Command Window. This was especially necessary for the LLMW alternatives: each of the CH-LLMW cases ran for approximately 2 to 4 hours on a Pentium ${ }^{\mathrm{TM}}$ processor. 
TABLE 17 Throughput and Contaminant Profiles by Site and Technology

Radionuclide Thruput and Air Release by Site and Technology

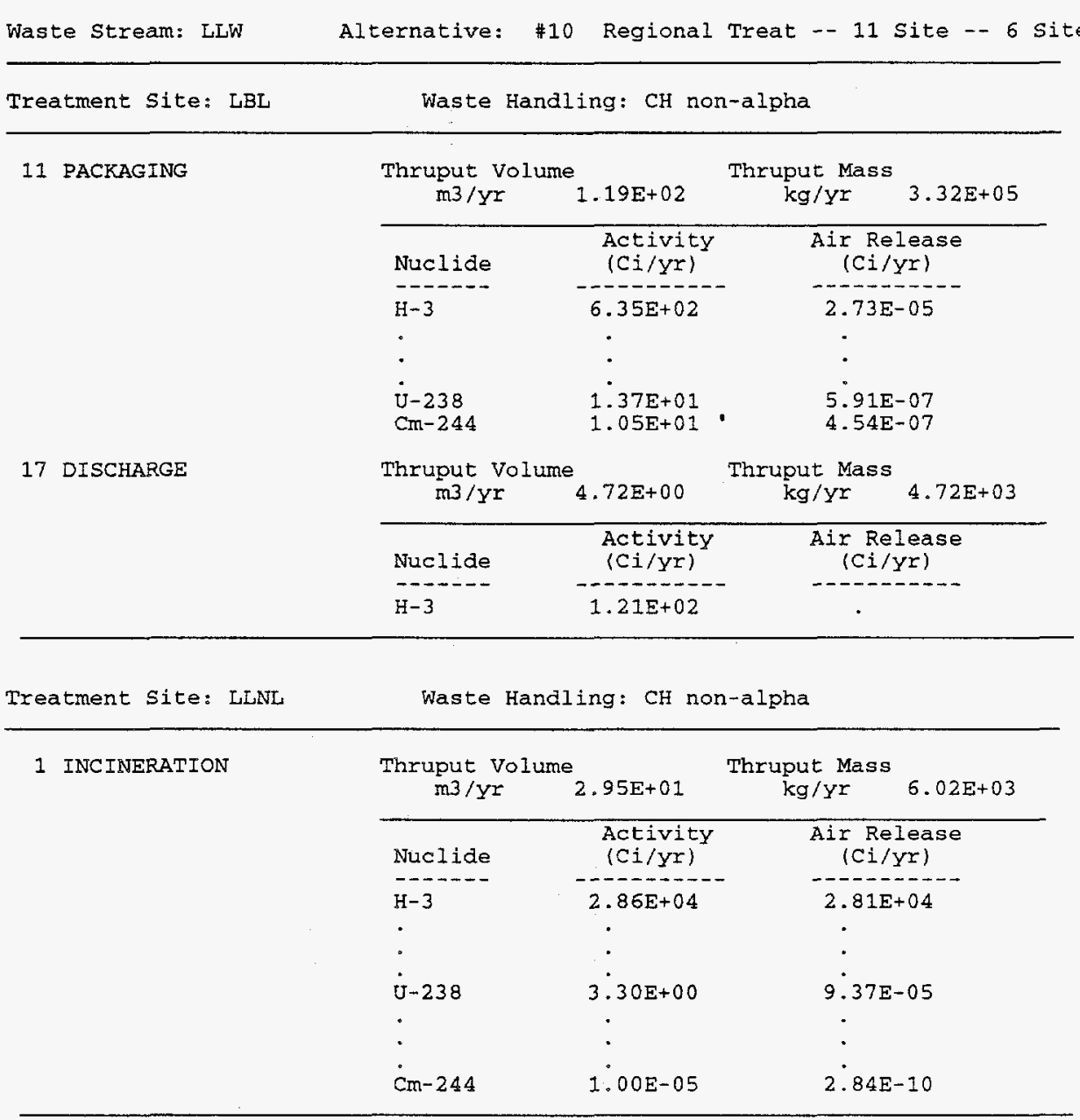

Chemical Thruput and Air Release by Site and Technology

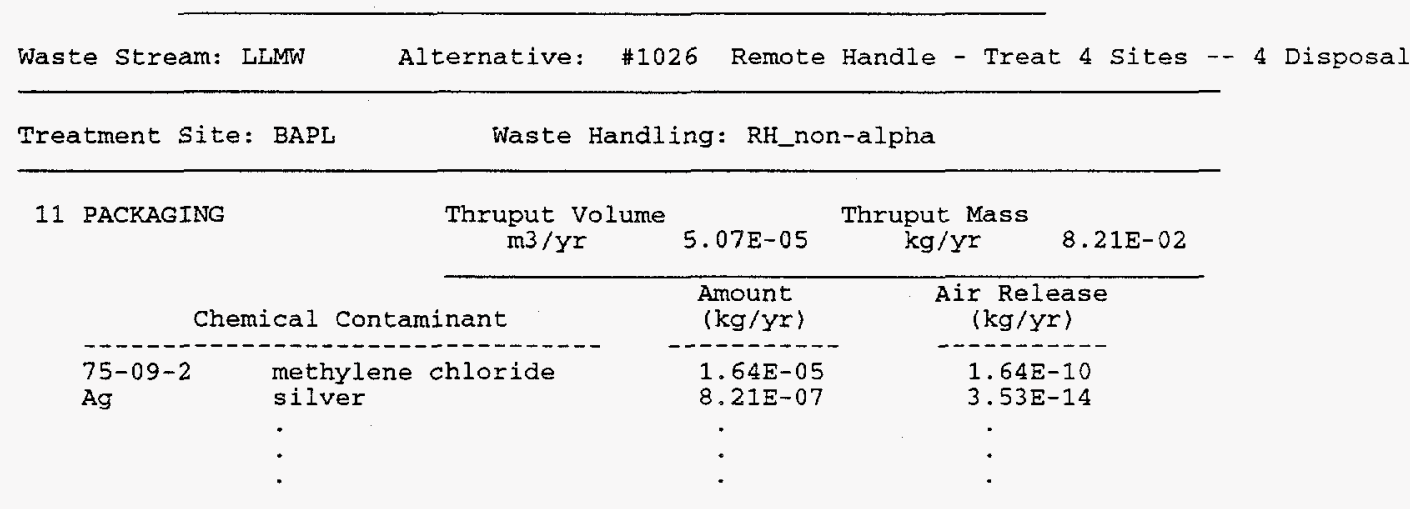

These output tables provide a summary of the throughput, contaminant air release, and groundwater discharges by site. They will contain entries for each generating site, treatment site, and disposal site and for each treatment technology that are included in the given alternative. 
TABLE 18 Representative WASTE_MGMT Execution Times and File Sizes

\begin{tabular}{|c|c|c|c|c|c|c|c|c|c|}
\hline \multirow[b]{3}{*}{ Waste Type } & \multirow{3}{*}{$\begin{array}{l}\text { Number } \\
\text { of Sites }\end{array}$} & \multirow{2}{*}{\multicolumn{3}{|c|}{ Input Streams ${ }^{\mathbf{a}}$}} & \multirow{3}{*}{$\begin{array}{c}\text { Final } \\
\text { Products }\end{array}$} & \multirow{3}{*}{$\begin{array}{c}\text { Total } \\
\text { Streams }^{c}\end{array}$} & \multicolumn{2}{|c|}{$\operatorname{Time}^{\mathrm{d}}(\mathrm{s})$} & \multirow{3}{*}{$\begin{array}{l}\text { Output } \\
\text { (Kbyte) }\end{array}$} \\
\hline & & & & & & & & & \\
\hline & & $\mathrm{i}$ & $\mathbf{n}$ & $\mathrm{h}$ & & & Elapsed & $\begin{array}{l}\text { Average } \\
\text { per Input }\end{array}$ & \\
\hline LLW & 30 & 117 & 21 & & 169 & 643 & 226 & 1.9 & 1,633 \\
\hline ER-LLW & 16 & 104 & 17 & & 120 & 362 & 105 & 1.0 & 761 \\
\hline CH-TRUW & 13 & 56 & 15 & 12 & 138 & 814 & 1,200 & 21.4 & 1,934 \\
\hline ER-TRUW & 5 & 8 & 12 & 8 & 33 & 188 & 325 & 40.6 & 518 \\
\hline CH-LLMW & 38 & 331 & 19 & 12 & 2,138 & 8,761 & 13,983 & 42.2 & 34,799 \\
\hline CH $\alpha$-LLMW & 9 & 73 & 14 & 12 & 503 & 1,994 & 3,032 & 41.5 & 6,656 \\
\hline ER-LLMW & 14 & 129 & 18 & 13 & 596 & 2,553 & 3,470 & 26.9 & 10,633 \\
\hline
\end{tabular}

a $\mathrm{i}=$ total number of input streams by generating site, handling characteristic, and treatability; $\mathrm{n}=$ average number of nuclides per stream;

$\mathrm{h}=$ average number of hazardous contaminants per stream.

b Total number of disposal products generated by treatment of all secondary streams.

c All substreams paths traversed.

d Total elapsed time and average time per input stream for running the computational model and generating a standard set of summary files and listings.

e Sizes for primary output files; does not include the summary files. 


\section{FURTHER DEVELOPMENT OF THE WASTE_MGMT MODEL}

The fragmentation of analyses for the WM PEIS was necessitated by the division of labor among the organizations participating in preparation of the document and by the tight schedules involved. Under different conditions, this fragmentation could be avoided, and WASTE_MGMT could be expanded into an integrated model that could calculate costs and environmental impacts associated with a given waste management strategy. For example, site-specific and radionuclide-specific unit risk factors (risk per unit release) could be incorporated into the WASTE_MGMT model as a data file, and the risks resulting from facility operations could then be calculated within the model by simple multiplication of the released quantities and the unit risk factors.

Cost curves have been developed for the generic TSD facilities used in the WM PEIS analyses. These curves define the costs of constructing and operating a facility as a function of the size of the facility (i.e., the quantity of waste processed at the facility). Such cost curves could also be incorporated into the WASTE_MGMT computational model, and the model could then be used to estimate the facility costs associated with a given strategy. This process would be accomplished by interpolating on the cost curves for facility waste loads that correspond to the given strategy.

In its fully developed form, the WASTE_MGMT model could be used to estimate the costs, risks, and resource requirements (e.g., staffing, energy, materials, and land) for a given waste management strategy at DOE installations. The model would be useful for DOE strategic planning efforts beyond the WM PEIS.

Finally, the model could be equipped with a user-friendly graphical interface to facilitate its use by individuals who are not so familiar with the design of the model. In addition, the model could be optimized so that running times for complex cases are reduced. Alternatively, the results of complex cases from prior runs could be cataloged, and these could be used, through the user interface, to provide quick responses to questions frequently asked by the public or the DOE strategic planners. Such improvements would greatly increase the usefulness of the model to future WM PEIS work, as well as to the DOE waste management strategic planners. 


\section{REFERENCES}

DOE: see U.S. Department of Energy.

Goyette, M.L., 1995, Low-Level Waste Inventory, Characteristics, Generation, and Facility Assessment for Treatment, Storage, and Disposal Alternatives Considered in the U.S. Department of Energy Waste Management Programmatic Environmental Impact Statement, ANL/EAD/TM-20 (Draft), Argonne National Laboratory, Argonne, Ill.

Hong, K., et al., 1995, Transuranic Waste Inventory, Generation, and Facility Assessment for Treatment, Storage, and Disposal Alternatives Considered in the U.S. Department of Energy Waste Management Programmatic Environmental Impact Statement, ANL/EAD/TM-22 (Draft), Argonne National Laboratory, Argonne, Ill.

Monette, F.A., et al., 1995a, Supplemental Information Related to Risk Assessment for the OffSite Transportation of Low-Level Waste the U.S. Department of Energy Waste Management Programmatic Environmental Impact Statement, ANL/EAD/TM-23 (Draft), Argonne National Laboratory, Argonne, Ill.

Monette, F.A., et al., 1995b, Supplemental Information Related to Risk Assessment for the OffSite Transportation of Low-Level Mixed Waste the U.S. Department of Energy Waste Management Programmatic Environmental Impact Statement, ANL/EAD/TM-35 (Draft), Argonne National Laboratory, Argonne, Ill.

Monette, F.A., et al., 1995c, Supplemental Information Related to Risk Assessment for the OffSite Transportation of Transuranic Waste the U.S. Department of Energy Environmental Management Programmatic Environmental Impact Statement, ANL/EAD/TM-27 (Draft), Argonne National Laboratory, Argonne, Ill.

Mueller, C., et al., 1995, Analysis of Accident Sequences and Source Terms for Waste Treatment and Storage Operations and Related Facilities for the U.S. Department of Energy Waste Management Programmatic Environmental Impact Statement, ANL/EAD/TM-29 (Draft), Argonne National Laboratory, Argonne, Ill.

Musgrave, B., 1995, Analysis of Waste Treatment Requirements for DOE Mixed Wastes, Technical Basis, BCMusgrave Incorporated, Livermore, Calif.

Palmer, B., 1995, [TBD], Los Alamos National Laboratory, Los Alamos, N.M.

U.S. Department of Energy, 1995, Office of Waste Management Programmatic Environmental Impact Statement, Draft, Washington, D.C. 
Wilkins, B., et al., 1995, Supplemental Information Related to Low-Level Mixed Waste Inventory, Generation, and Facility Assessment for Treatment, Storage, and Disposal Alternatives Considered in the U.S. Department of Energy Waste Management Programmatic Environmental Impact Statement, ANL/EAD/TM-32 (Draft), Argonne National Laboratory, Argonne, Ill. 


\section{APPENDIX:}

\section{WASTE_MGMT FILES}

\section{A.1 FILE NAMES AND EXTENSIONS}

The input and output files described in Sections A.2 and A.3 are of three file types that are distinguished by the file name extension. Files with names that end in ".DBF" have the FoxPro ${ }^{\circledR}$ database format. Files with names that end in ".LST" are ASCII listing files with fixed length records that include page control characters for printed output. Files with names that end in ".DAT" are ASCII text files with varying length records terminated by carriage return and line feed characters.

Output files generated by the WASTE_MGMT model are created with unique file names that include the alternative number. The following generic output file names are completed by appending a four-digit alternative number to the root name. For example, the file THRT0010.DBF is the primary output file containing volume and mass throughput for LLW alternative 10. The alternative numbers were constructed to distinguish the waste type because the WM PEIS case definitions are enumerated separately for each of the waste types: LLW alternative numbers begin with the "0" (e.g., 0010), and ER-LLW numbers begin with "3" (e.g., 3008). In addition, some cases that were added later as WM PEIS cases have slightly altered numbers, e.g., LLW case 14 a has alternative number (0114) to distinguish it from case 14 (0014). A special situation occurred for processing the LLMW cases. Because of long execution times and large output file sizes, the LLMW cases were defined for CH nonalpha waste with alternative numbers that begin with "10", e.g., LLMW case 10 (1010), and the same cases were defined for $\mathrm{CH}$ alpha waste with numbers that begin with "11" (1110). The alternative numbering convention is summarized in Table A.1.

TABLE A.1 Alternative Numbering Convention

\begin{tabular}{|c|c|}
\hline $\begin{array}{l}\text { WM PEIS } \\
\text { Waste Type }\end{array}$ & $\begin{array}{l}\text { WASTE_MGMT } \\
\text { File Suffix }^{\mathbf{a}}\end{array}$ \\
\hline WM-LLW & $00 \mathrm{nn}$ or $01 \mathrm{nn}$ \\
\hline ER-LLW & $30 \mathrm{nn}$ \\
\hline EM-LLMW & $10 \mathrm{nn}$ or $11 \mathrm{nn}$ \\
\hline ER-LLMW & $40 n n$ \\
\hline WM-TRUW & $20 n n$ \\
\hline ER-TRUW & $50 \mathrm{nn}$ \\
\hline
\end{tabular}

a " $\mathrm{n} n$ " is the 2-digit WM PEIS case number. 


\section{A.2 MODEL INPUT FILES}

\section{A.2.1 Waste Inventory and Characterization Files}

Waste inventory and characterization files describe the waste streams that are processed by WASTE_MGMT in a standard form. The volume and mass values are defined as the net volume of untreated waste that is processed annually, and the mass is the net volume times the waste stream density determined by waste type and treatability category. Data that describe specific waste types are usually obtained from sources in other formats, and the data may require transformation to the standard form expected by the model. For example, waste volumes that include voids due to partially packed waste containers are gross volumes. These gross volumes are normalized to the standard stream densities defined by the model. Similar transformations may apply to the specification of contaminant profiles. Descriptions of the waste inventory and characterization for LLW, LLMW and TRUW are found, respectively, in Appendices K, L and M of DOE (1995), and in Goyette (1995), Wilkins et al. (1995), and Hong et al. (1995).

THR.DBF

NUC.DBF

CHM.DBF
The generic name THR.DBF applies to several database files that contain waste inventory and generation data. The records identify waste streams by waste type, generating site, handling characteristic, and treatability category; they include the assumed density of the waste stream as it is processed by WASTE_MGMT, the generation and processing periods, and the effective annual volume $\left(\mathrm{m}^{3} / \mathrm{yr}\right)$ and mass $(\mathrm{kg} / \mathrm{yr})$ processing throughput rates. The actual names of the files are specific to the waste type: THRU_GRP (LLW), ER_THR(ER-LLW), TRUW_THR (TRUW), ERTR_THR (ER-TRUW), MLLW_THR (LLMW), and ERML_THR (ER-LLMW).

The generic name NUC.DBF applies to several database files that contain the radiological profiles ( $\mathrm{Ci} / \mathrm{yr}$ by nuclide) of waste streams. Common fields link the records with the associated waste streams of THR.DBF. The actual file names are specific to the waste type: FEED_NUC (LLW), ER_NUC (ER-LLW), TRUW_NUC (TRUW), ERTR_NUC (ER-TRUW), MLLW_NUC (LLMW), and ERML_NUC (ER-LLMW).

The generic name CHM.DBF applies to several database files that contain the hazardous contaminant profiles (kg/yr by contaminant) of waste streams. Common fields link the records with the associated waste streams of THR.DBF. The actual names of the files are specific to the waste type: TRUW_CHM (TRUW), ERTR_CHM (ER-TRUWW), MLLW_CHM (LLMW), and ERML_CHM (ER-LLMW). 


\section{A.2.2 TSD Facility Characterization Files}

The TSD facility characterization files are constructed independently of the WASTE_MGMT model. The parameters that define the TSD modules are determined by waste-specific assumptions and waste characterization. Descriptions of the facility characterization parameters and assumptions for processing LLW, LLMW and TRUW are found, respectively, in Appendixes K, L, and M of DOE (1995), and in Goyette (1995), Wilkins et al. (1995), and Hong et al. (1995).

TCH_PRAM.DBF The TCH_PRAM.DBF file contains parameters that describe the treatment, storage, and disposal technologies. The records are identified by waste type and technology. Some technologies may be sensitive to waste-handling characteristic or treatability category, and distinct entries for those technologies appear for all necessary handling characteristics or treatability categories. Each record contains partitioning coefficients for the bulk parameters: the volume concentration or expansion of the product output stream relative to the input volume (product volume/input volume), the mass fraction of the product stream relative to the input mass (product mass/input mass), the mass fractions of secondary output streams relative to the input mass (secondary stream mass/input mass), and the densities of the secondary output streams. The record may also contain other data, for example, process input such as fuel, water and process additives. However, the current version of WASTE_MGMT does not use these additional parameters.

REL_FRAC.DBF The REL_FRAC.DBF file defines the fractional partitioning of the radiological contaminants among the output streams $(\mathrm{Ci}$ output/Ci input, by output stream) and a release to the atmosphere (Ci released/Ci input). The records are identified by waste type and technology, and also by waste-handling characteristic and treatability category corresponding with entries in TCH_PRAM. For a given technology, records may be specific to nuclides that vary significantly in the partitioning among different physical forms or phases, for example, tritium exchanges with other hydrogen and so is easily released to the atmosphere, whereas cesium and radium may be present as water-soluble salts. At least one record is made for each corresponding entry in TCH_PRAM, with the generic nuclide identity "All Oth" that specifies the partitioning coefficients for all other radionuclides not specifically listed. 
REL_CHEM.DBF The REL_CHEM.DBF file defines the fractional partitioning of the hazardous contaminants among the output streams (kg output/ $\mathrm{kg}$ input, by output stream) and a release to the atmosphere ( $\mathrm{kg}$ released $/ \mathrm{kg}$ input). The records also contain a field for the destructive removal or neutralization of contaminants. The records are identified by waste type and technology, and also by wastehandling characteristic and treatability category corresponding with entries in TCH_PRAM. Currently, records are specific for each contaminant that appears in the generic waste streams defined for a given waste type.

\section{A.2.3 Alternative Definition Files}

Alternative definition files incorporate the case definitions for treatment, storage, and disposal alternatives. Descriptions of the WM PEIS case definitions for LLW, LLMW, and TRUW are found in Chapter 2 of DOE (1995) and summarized in Appendices K, L, and $\mathrm{M}$ of the same document.

ALTERNTS.DBF The ALTERNTS.DBF file describes the sequence of treatment technologies and treatment and disposal locations for each inventory waste stream. The records are specific to each WM PEIS case definition, and a unique alternative number is assigned to each case that is included in all output files and is used to create unique output file names. In the current model, two pretreatments can be specified at the generating site, followed by as many as six treatments at a treatment site, and a disposal method at the disposal site. Each waste stream at a generating site will be represented by one or more records that specify the sequence of treatments applied to produce a final output product - either solidified or stabilized waste, or treated water discharge. Each unique secondary output stream (substream) encountered in the treatment sequence will have one record and final form component.

ALTERNTV.DBF The ALTERNTV.DBF file contains the descriptive title of each WM PEIS case that is used in summary output listings. The entries in the file are linked to ALTERNTS by the unique alternative number.

\section{A.3 MODEL OUTPUT FILES}

\section{A.3.1 Primary Output Files}

Primary output files are created for each execution of the WASTE_MGMT model. These files capture all of the detail of processing individual waste streams through the 
complete treatment trains specified in ALTERNTS. The file names are constructed from the root names shown below, but with the unique alternative number appended. For example, one of the output files for LLW case 9 is THRT0009.DBF, whereas the corresponding file for ER-LLW case 9 is THRT3009.DBF. The alternative numbering convention is summarized in Table A.1.

THRT.DBF The THRT.DBF file contains the volume $\left(\mathrm{m}^{3} / \mathrm{yr}\right)$ and mass $(\mathrm{kg} / \mathrm{yr})$ of the waste substreams that are input to each TSD module. The records are uniquely identified by waste type, generating site, handling characteristic, treatability category, and a character sequence constructed from an abbreviation of the preceding substream names. The entries also include the previous site, previous TSD module, previous TSD output stream, current site, and current TSD module. As noted above, these files are specific to each WM PEIS case and have file names that include the corresponding alternative number. For example, the file for TRUW case 10 is named THRT2010.DBF.

THRN.DBF THRC.DBF

\section{AIRN.DBF} AIRC.DBF
THRN contains the radiological profiles $(\mathrm{Ci} / \mathrm{yr})$ for the substreams identified in THRT. THRC contains the hazardous contaminant profiles $(\mathrm{kg} / \mathrm{yr})$ for the substreams identified in THRT. Entries are linked to THRT by waste type, generating site, handling characteristic, treatability category, and substream sequence. File names are formed by the method described above, for example, THRN2010.DBF.

AIRN contains air emissions of radionuclides ( $\mathrm{nCi} / \mathrm{yr}$ ) associated with the TSD modules in THRT. AIRC contains air emissions of hazardous contaminants ( $\mu \mathrm{g} / \mathrm{yr}$ ) associated with the TSD modules in THRT. Entries are linked to THRT by waste type, generating site, handling characteristic, treatability category, and substream sequence. File names are formed by the method described above, for example, AIRN2010.DBF.

\section{A.3.2 Summary DBF Files}

Summary DBF Files are aggregations of the primary output files that are more useful for subsequent analyses. Summaries are most frequently created by treatment site, by treatment technology, by handling characteristic or by treatability category, and by various combinations of these. Unique file names are created by appending the alternative number to the root names shown here (Section A.1). 
AIRR.DBF CHMR.DBF

AIRS.DBF CHMS.DBF

DSTV.DBF

DSTN.DBF DSTC.DBF

DSPR.DBF DSPH.DBF
AIRR summarizes the throughput volumes, masses, radiological profiles $(\mathrm{Ci} / \mathrm{yr})$, and air emissions $(\mathrm{nCi} / \mathrm{yr})$ by treatment site, TSD module, and handling characteristic. CHMR summarizes the throughput volumes, masses, and hazardous contaminant profiles $(\mathrm{kg} / \mathrm{yr})$, and air emissions ( $\mu \mathrm{g} / \mathrm{yr}$ ) in the same manner. (A related file for LLW is AIXR.DBF, which includes radiological profiles for the first 10-year period during which only aqueous streams and Hanford grout wastes and Savannah River saltstone wastes were processed.)

AIRS summarizes the radiological profiles ( $\mathrm{Ci} / \mathrm{yr}$ ) and air emissions ( $\mathrm{nCi} / \mathrm{yr}$ ) by treatment site and handling characteristic. CHMS summarizes the hazardous contaminant profiles $(\mathrm{kg} / \mathrm{yr})$ and air emissions ( $\mu \mathrm{g} / \mathrm{yr}$ ) in the same manner. (A related file for LLW is AIXS.DBF, which includes radiological profiles for the first 10-year period during which only aqueous streams and Hanford grout wastes and Savannah River saltstone wastes were processed.)

The DSTV.DBF file contains the total volume $\left(\mathrm{m}^{3}\right)$ and mass $(\mathrm{kg})$ of disposed waste for the processing period defined for the WM PEIS case. The totals are given by disposal site and disposal method and by the handling characteristic and treatability category of the original waste.

DSTN contains the radiological profile $(\mathrm{Ci})$ for the total volume of disposed waste and cumulative air emissions ( $\mathrm{nCi}$ ) of the waste specified in DSTV. Similarly, DSTC contains the hazardous contaminant profile $(\mathrm{kg})$ for the total volume of disposed waste and cumulative air emissions $(\mu \mathrm{g})$ of the waste specified in DSTV.

DSPR contains the total volume $\left(\mathrm{m}^{3}\right)$, mass $(\mathrm{kg})$, radiological profile (Ci), and cumulative air emissions ( $\mathrm{nCi}$ ) of disposed waste for the processing period defined for the WM PEIS case. The totals are given by disposal site and disposal method, combined for all wastehandling characteristics and treatability categories. Similarly, DSPH contains the total volume $\left(\mathrm{m}^{3}\right)$, mass $(\mathrm{kg})$, hazardous contaminant profile ( $\mathrm{kg})$, and cumulative air emissions $(\mu \mathrm{g})$ of disposed waste for the processing period defined for the WM PEIS case. 
INCT.DBF

INCN.DBF INCC.DBF

TRTT.DBF

TRTN.DBF TRTC.DBF

TTEC.DBF

TNUC.DBF TCHM.DBF

XSIT.DBF
The INCT.DBF file is a subset of the primary output file THRT. The subset includes throughput of LLMW or TRUW substreams for incineration, and the substreams are assigned to intermediate categories with common physical characteristics. For example, treatability category 81 was defined to be untreated organic liquid intermediates, and it included LLMW treatability categories 03, 04, 05 , and 06 , as well as organic liquid substreams that are sent for incineration.

INCN contains the radiological profiles of the substreams included in INCT. Similarly, INCC contains the hazardous contaminant profiles of substreams included in INCT.

The TRTT.DBF file summarizes the volume and mass throughput by treatment site, TSD module, handling characteristic, and treatability category. (A related file for LLW is TXTT.DBF, which includes the first 10-year period during which only selected waste streams were processed.)

TRTN summarizes the radiological profiles ( $\mathrm{Ci} / \mathrm{yr}$ ) and air emissions ( $\mathrm{nCi} / \mathrm{yr}$ ) by treatment site, TSD module, handling characteristic, and treatability category. TRTC summarizes the hazardous contaminant profiles $(\mathrm{kg} / \mathrm{yr})$ and air emissions $(\mu \mathrm{g} / \mathrm{yr})$ in the same manner. Common fields of TRTN and TRTC link corresponding records in TRTT. (A related file for LLW is TXTN.DBF, which includes radiological profiles for the first 10-year period during which only aqueous streams and Hanford grout wastes and Savannah River saltstone wastes were processed.)

The TTEC.DBF file summarizes the volume and mass throughput by treatment site, TSD module, and handling characteristic.

TNUC summarizes the radiological profiles $(\mathrm{Ci} / \mathrm{yr})$ and air emissions ( $\mathrm{nCi} / \mathrm{yr}$ ) by treatment site, TSD module, and handling characteristic. TCHM summarizes the hazardous contaminant profiles $(\mathrm{kg} / \mathrm{yr})$ and air emissions ( $\mu \mathrm{g} / \mathrm{yr}$ ) in the same manner. Common fields of TNUC and TCHM link corresponding records in TTEC.

The XSIT.DBF file summarizes the volume and mass throughput for transported wastes by shipping site, destination site, and handling characteristic. 
XNUC.DBF

XCHM.DBF
XNUC summarizes the radiological profiles ( $\mathrm{Ci} / \mathrm{yr}$ ) for transported wastes by shipping site, destination site, and handling characteristic. $\mathrm{XCHM}$ summarizes hazardous contaminant profiles $(\mathrm{kg} / \mathrm{yr})$ in the same manner. Common fields of XNUC and XCHM link corresponding records in XSIT.

\section{A.3.3 Summary ASCII Files}

Summary ASCII files are data files or print files generated from primary and summary database files. Generally, hard copies of the print files are produced only for reference and to facilitate quality assurance. Electronic copies of these listings are made available for distribution. Unique file names are created by appending the alternative number to the root names shown here (Section A.1).

AIRR.LST

CHMR.LST

AIRS.LST CHMS.LST

DSPV.LST

DSPR.LST DSPH.LST
AIRR is a formatted listing of throughput volumes, masses, radiological profiles $(\mathrm{Ci} / \mathrm{yr}$ ), and air emissions ( $\mathrm{nCi} / \mathrm{yr}$ ) by treatment site, TSD module, and handling characteristic. Similarly, CHMR is a listing of throughput volumes, masses, and hazardous contaminant profiles $(\mathrm{kg} / \mathrm{yr})$ and air emissions $(\mu \mathrm{g} / \mathrm{yr})$ organized in the same manner.

AIRS is a formatted listing of radiological profiles ( $\mathrm{Ci} / \mathrm{yr})$ and air emissions ( $\mathrm{nCi} / \mathrm{yr}$ ) by treatment site and handling characteristic. Similarly, CHMS is a listing of hazardous contaminant profiles $(\mathrm{kg} / \mathrm{yr})$ and air emissions ( $\mu \mathrm{g} / \mathrm{yr}$ ) organized in the same manner.

The DSPV.LST is a formatted listing of total volume $\left(\mathrm{m}^{3}\right)$ and mass (kg) of disposed waste for the processing period defined for the WM PEIS case. The totals are given by disposal site and disposal method, and by the handling characteristic and treatability category of the original waste.

DSPR is a formatted listing of total volume $\left(\mathrm{m}^{3}\right)$, mass $(\mathrm{kg})$, radiological profile (Ci), and cumulative air emissions ( $\mathrm{nCi}$ ) of disposed waste for the processing period defined for the WM PEIS case. The totals are given by disposal site and disposal method, combined for all waste-handling characteristics and treatability categories. Similarly, DSPH is a formatted listing of total volume $\left(\mathrm{m}^{3}\right)$, mass $(\mathrm{kg})$, hazardous contaminant profile $(\mathrm{kg})$, and cumulative air emissions $(\mu \mathrm{g})$ of disposed waste for the processing period defined for the WM PEIS case. 
THRU.LST

TRNS.LST

TRAN.LST TRAC.LST

TRI5.DAT TRX5.DAT TRCH.DAT TRC1.DAT TRCT.DAT
The THRU.LST print file summarizes the volume and mass throughput by treatment site, TSD module, handling characteristic, treatability category, and generating site. (A related file for LLW is THXU.LST, which includes the first 10-year period during which only selected waste streams were processed.)

The TRNS.LST print file summarizes the volume and mass of transported waste by shipping site, destination, handling characteristic, treatability category, and generating site of original waste. (A related file for LLW is TRXS.LST, which includes the first 10-year period during which only aqueous streams and Hanford grout wastes and Savannah River saltstone wastes were processed.)

TRAN is a formatted listing of volumes, masses, and radiological profiles $(\mathrm{Ci} / \mathrm{yr})$ for transported wastes by shipping site, destination site, and handling characteristic. Similarly, TRAC lists volumes, masses, and hazardous contaminant profiles (kg/yr) in the same manner.

The TR15, TRX5, TRCH, TRC1, and TRCT text files contain summaries of volume and mass and radiological profiles of transported waste by shipping site and destination. The files have a common format specified for input to the transportation risk analysis code used at ANL-E. The file names distinguish subsets of the waste treatability categories, grouped for purposes of analysis. TRI5 contains data for LLW activated metal, whereas TRX5 contains data for all other LLW treatability categories. TRC1 contains data for CH-LLMW or CH-TRUW untreated organic liquids, whereas TRCH contains data for all other CH-LLMW or CH-TRUW treatability categories of untreated waste. TRCT contains data for all treatability categories of LLMW or TRUW treated waste. (TRRH and TRRT are similar files for RH-LLMW or RH-TRUW.) 